\title{
Design and quantification of an extreme winter storm scenario for emergency preparedness and planning exercises in California
}

\author{
Michael D. Dettinger - F. Martin Ralph • Mimi Hughes • \\ Tapash Das • Paul Neiman • Dale Cox • Gary Estes • David Reynolds • \\ Robert Hartman · Daniel Cayan $\cdot$ Lucy Jones
}

Received: 14 March 2011/Accepted: 1 July 2011/Published online: 13 July 2011

(C) The Author(s) 2011. This article is published with open access at Springerlink.com

\begin{abstract}
The USGS Multihazards Project is working with numerous agencies to evaluate and plan for hazards and damages that could be caused by extreme winter storms impacting California. Atmospheric and hydrological aspects of a hypothetical storm scenario have been quantified as a basis for estimation of human, infrastructure, economic, and environmental impacts for emergency-preparedness and flood-planning exercises. In order to ensure scientific defensibility and necessary levels of detail in the scenario description, selected historical storm episodes were concatentated to describe a rapid arrival of several major storms over the state, yielding precipitation totals and runoff rates beyond those occurring during the individual historical storms. This concatenation allowed the scenario designers to avoid arbitrary scalings and is based on historical occasions from the 19th and 20th Centuries when storms have stalled over the state and when extreme
\end{abstract}

M. D. Dettinger $(\bowtie) \cdot$ D. Cayan

U.S. Geological Survey, Scripps Institution of Oceanography, La Jolla, CA, USA

e-mail: mdettinger@ucsd.edu

F. Martin Ralph · M. Hughes · P. Neiman

NOAA/Earth System Research Laboratory/Physical Sciences Division, Boulder, CO, USA

T. Das

Scripps Institution of Oceanography, La Jolla, CA, USA

D. Cox

US Geological Survey Multihazards Demonstration Program, Sacramento, CA, USA

G. Estes

California Extreme Precipitation Symposium, Auburn, CA, USA

D. Reynolds

National Weather Service, Monterey, CA, USA

R. Hartman

NOAA/NWS California-Nevada River Forecast Center, Sacramento, CA, USA

L. Jones

US Geological Survey Multihazards Demonstration Program, Pasadena, CA, USA 
storms have arrived in rapid succession. Dynamically consistent, hourly precipitation, temperatures, barometric pressures (for consideration of storm surges and coastal erosion), and winds over California were developed for the so-called ARkStorm scenario by downscaling the concatenated global records of the historical storm sequences onto 6- and 2-km grids using a regional weather model of January 1969 and February 1986 storm conditions. The weather model outputs were then used to force a hydrologic model to simulate ARkStorm runoff, to better understand resulting flooding risks. Methods used to build this scenario can be applied to other emergency, nonemergency and non-California applications.

Keywords Storm hazards - California - Flood - Scenario - Emergency preparedness · Disaster management

$\begin{array}{ll}\text { Abbreviations } & \\ \text { AR } & \text { Atmospheric river } \\ \text { WRF model } & \text { Weather Research and Forecast model } \\ \text { NNRP } & \text { National Centers for Environmental Protection/National Center for } \\ & \text { Atmospheric Research Reanalysis Project } \\ \text { UTC } & \text { Coordinated Universal Time (Greenwich Mean Time) } \\ \text { VIC model } & \text { Variable Infiltration Capacity (hydrologic) model }\end{array}$

\section{Introduction}

West Coast winter storms are natural phenomena that have always challenged Californians as major hazards. The storms are not as notorious as hurricanes in the southeastern U.S., but they rival hurricanes in important ways. West Coast winter storms bring comparable winds (in some storm sectors), comparably large rainfall totals, and major floods, storm surges and surf, and coastal erosion. Nonetheless, winter storms have often been considered as normal on the West Coast, in part, because the most extreme historical West Coast storms occurred prior to modern data gathering and decades before current populations were born (e.g., in 1862). Thus, these most extreme historical storms are treated as quasimythological events rather than real incidents to be accommodated in planning. Major investments in flood control infrastructure have reduced risks from storms, but the risk of catastrophic flooding remains very real, as evidenced by major floods in 1986 and 1997, and by the continuing history of flood-caused levee breaches in the Central Valley (Florsheim and Dettinger 2007). The 1986 and 1997 storms came close to overwhelming flood-control systems, threatening inundation of downtown Sacramento, and led to National Research Council studies (NRC 1995, 1999), planned major enhancements to flood control, and long-term research (e.g., Ralph et al. 2005a).

The U.S. Geological Survey's (USGS's) Multihazards Demonstration Project uses hazards science to improve community resilience to natural disasters, including earthquakes, tsunamis, wildfires, landslides, and floods. The first public Multihazards Project product was the Great California Shakeout Earthquake Scenario (Perry et al. 2008), a detailed scenario describing physical conditions during and following a hypothetical magnitude 7.8 earthquake on the San Andreas fault zone in Southern California. Emergency planning and preparedness exercises based on this scenario involved over 300 
scientists, 5,000 emergency responders and disaster recovery agents, and the participation of over 5.5 million citizens (http://www.shakeout.org/).

The "ARkStorm" Scenario described herein (more about this title below) represents the second major public project by the Multihazards Project. In the ARkStorm case, a major winter storm sequence-surpassing many of the historical "design storms" used in current structural and planning designs-is the focus. Experts are examining this scenario's physical, socioeconomic, and environmental consequences, addressing possibilities, costs, and consequences of resulting floods, landslides, and debris flows, coastal erosion and inundation, wind damage, pollution dispersal, threats to endangered species, and physical damages like bridge scour, road closures, dam and levee failures, property loss, water- and power-supply disruptions, and long-term recovery conditions. Dozens of emergency preparedness, first-responder, and resource management experts and organizations have been interviewed to evaluate preparedness for such a storm with results reported by Porter et al. (2011). Through a series of workshops and media reports, the public is being invited to learn more about consequences of winter storms in California and to prepare for their safety and that of families, communities, properties, and livelihoods.

Although meteorological understanding of midlatitude cyclones that make landfall on the West Coast has a long history (e.g., Weaver 1962), and the "pineapple express" storm configuration is well known by meteorologists and the public (Higgins et al. 2000; Dettinger 2004), scientific and technological advances have only recently documented just how strong such storms can be and how they become so strong. That understanding has involved recognition of the significance of a key feature within the storms that is only recently observable by satellites, the "atmospheric river" (AR; e.g., Zhu and Newell 1998; Ralph et al. 2004). AR storms that impact California are a result of low-level jets along the zones just ahead of the cold front in warm sectors of major winter cyclones over the eastern North Pacific. To put these west coast AR storms into perspective, consider that they routinely include winds reaching more than $40 \mathrm{~m} \mathrm{~s}^{-1}$, approaching those in category 2 hurricanes (Ralph et al. 2005b). The winds carry substantial water vapor, with vertically integrated water-vapor contents $>3 \mathrm{~cm}$ of water on average, reaching $5.5 \mathrm{~cm}$ (Neiman et al. 2008). This vapor transport is along narrow corridors more than $2,000 \mathrm{~km} \mathrm{long}$, a few hundreds of kilometers wide (e.g., as highlighted for a recent AR by satellite water vapor imagery in Fig. 1), in the lowest $\sim 2.5 \mathrm{~km}$ of the atmosphere (Ralph et al. 2004, 2005b). In combination, the winds and vapor contents yield large vapor transport rates (e.g., $>500 \mathrm{~kg}$ of water vapor per second across each meter of horizontal width of the corridors). The atmospheric profiles within these corridors tend to be moist-statically neutral in the lower $3 \mathrm{~km}$, so that when they encounter California's coastal ranges and Sierra Nevada, orographic uplift is strong and orographic precipitation is copious (e.g., Ralph et al. 2006). As a result of strong winds associated with extreme ARs and the low pressures associated with the cyclones, high waves and storm surges commonly accompany these storms, providing potential for active coastal erosion and inundation. Hazards posed by AR storms include damaging winds, extreme rainfall, flooding, debris flows and mudflows, heavy surf and coastal erosion, and deep mountain snows with transportation disruptions and avalanche risks.

Recent research (e.g., Ralph et al. 2006, and other references cited herein) has shown that extreme precipitation in California is most often the result of land-falling ARs. An intense AR striking the northern Sierra Nevada and flooding the State's capital, Sacramento, could be the California analogue to Hurricane Katrina hitting the Gulf of Mexico Coast and flooding New Orleans. Sacramento is no less at risk now than New Orleans was 


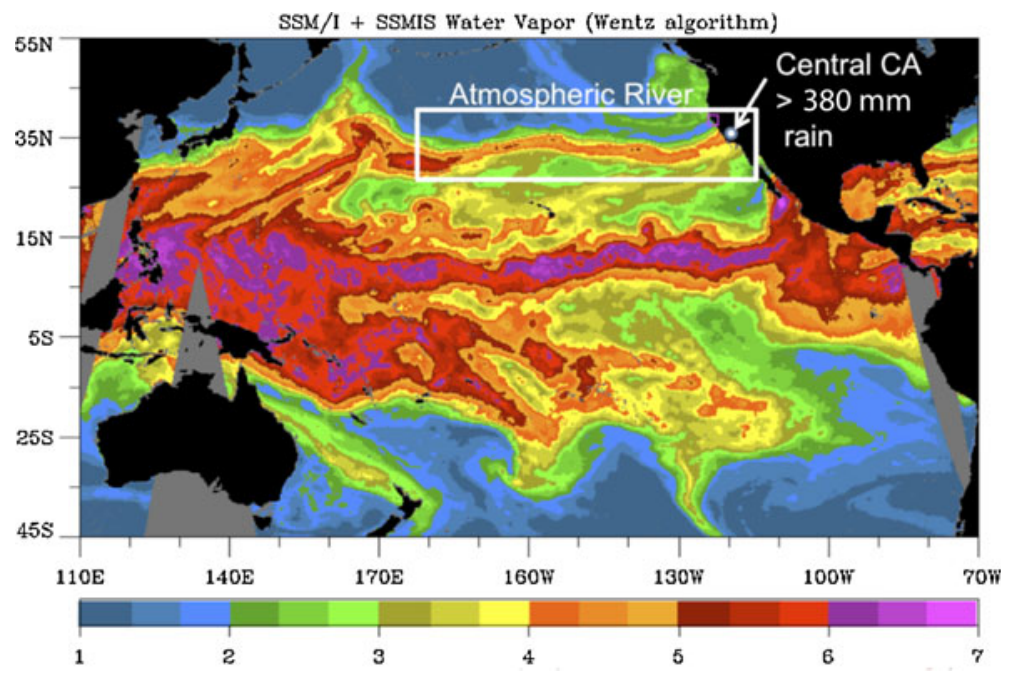

Fig. 1 Composite SSM/I satellite image of vertically integrated water vapor $\left(\mathrm{g} \mathrm{cm}^{-2}\right.$; color bar at bottom) constructed from polar-orbiting swaths in the $12 \mathrm{~h}$ prior to $10 \mathrm{am}$ UTC 14 October 2009. The atmospheric river indicated here channeled water vapor from a decaying typhoon over the western North Pacific, across nearly the entire width of the ocean basin, to deposit copious rains over the central coast of California

before Katrina (NRC 1995, 1999; California DWR 2005; Rehmeyer 2006). (Locations of California settings mentioned herein are indicated on various maps in this paper.)

This paper describes the design and quantification of a geographically, temporally, and atmospherically detailed scenario of an extreme sequence of AR storms impacting California. The scenario was branded the "ARkStorm" early in the project (with the help of students from the Arts Center College of Design, Pasadena, California) to highlight the fact that the most threatening storms in California are atmospheric river ("AR") storms (Ralph et al. 2006; Leung and Qian 2009), to highlight the intensity of the storm scenario (rising to 1,000 -year ("k") storm conditions in some areas), and by visual pun, to highlight the Noachian character ("ARk") of such storms, historical and hypothetical.

Intense and sustained winter storms from California's historical record-not least of which are the storms of the late 1800s (e.g., Kelley 1998)-provide both reality checks and motivations for developing a truly severe scenario, and are described next. Then the problems faced in constructing a realistic and detailed scenario of an extreme winter-storm sequence in California will be described and resolved, followed by a description of the resulting scenario.

\section{Major historical storms}

\subsection{Storms and floods of 1862}

The largest storm sequence in California's history is generally considered to be that of the winter of 1861-1862, although other storm seasons late in the 19th century rivaled it. The most intense rains fell in January 1862, with about $420 \%$ of normal falling in Sacramento, $519 \%$ in San Francisco, and 300\% in San Diego (Roden 1989). The unusually rainy season 
began on 24 December 1861 in Southern California, following what has been described as a "sunny, dry and warm" fall (Sadler 1957). In Northern California, rains in November and December 1861 contributed to early-season flooding, but the most intense period of storminess extended from 24 December 1861 through 21 January 1862, when rain fell on 28 of 30 days (Null and Hulbert 2007). Warm storm conditions exacerbated the storm's consequences by melting snowpack in large areas of the Sierra Nevada in December.

The result of these uninterrupted storms was flooding throughout the state. William Brewer, a Yale geologist, reported the Central Valley to be inundated on 19 January 1862, by icy cold, muddy water over an area as much as $500 \mathrm{~km}$ long and from 20 to $100 \mathrm{~km}$ wide (Engstrom 1996; Null and Hulbert 2007). Thousands of farms were inundated. Freshwater flow from the Central Valley, through the Golden Gate at San Francisco, to the Pacific Ocean, was large enough so that tidal fluctuations stopped at the outlet for nearly 2 weeks, and freshwater capped the surface of San Francisco Bay for 2-3 months (Engstrom 1996). Upstream where the Sacramento River from the northern Central Valley and the San Joaquin River from the southern Central Valley merge at California's Delta, southwest of Sacramento, the convergence of floods from multiple rivers backed water up in the Sacramento River for more than $45 \mathrm{~km}$ (Thompson 1957).

Flooding on the Santa Ana River (along the southern edge of Los Angeles) in Southern California lasted about 20 days; other recorded floods on that river have not lasted for more than four. Sadler (1957) estimated a peak Santa Ana River discharge of about 9,000 m³ compared to the highest modern measurements of 2,800 m $3 / \mathrm{s}$ in March 1938 and $500 \mathrm{~m}^{3} / \mathrm{s}$ in January 1969, although this latter flood occurred in an era of extensive flood-control facilities. Broad areas between Los Angeles and the ocean, in areas (Anaheim) farther south, and in the Mojave Desert were inundated in the 1862 storm. The San Gabriel River through the center of Los Angeles and the San Diego River both abandoned their previous channels to cut new paths to the sea (Engstrom 1996). Indeed, channel cutting was pervasive enough so that along-river water tables fell and agricultural in several areas required irrigation for the first time after the floods.

Besides an improved understanding of the possible scale of damages from a truly extreme storm in California, the scattered records of the events of 1862 provided two major lessons for the ARkStorm designers: First, a prolonged storm sequence with truly extreme precipitation totals is demonstrably possible, and, second, extreme storm sequences can strike northern and Southern California in rapid succession, e.g., peak flooding in Southern California occurred just 12 days after that in Sacramento in 1862.

\subsection{0th Century storms}

Major storms and floods in California during the modern-instrumental period (since about 1950) include events in 1950, 1955, 1964, 1969, 1986, 1997, and 2005. Retired California State Climatologist, Jim Goodrich, surveyed all available historical precipitation records and identified 54 instances when more than $380 \mathrm{~mm}$ (15 inches) of precipitation was recorded in 1 day at weather stations in California between 1871 and 1998. The rank distribution of such storms is shown in Fig. 2, with two storm days (25 January 1969 and 17 February 1986) that will figure prominently in the ARkStorm scenario highlighted.

Because much more data are available to describe the more recent episodes, the storms of 1969, 1986, and 1997 became a focus of ARkStorm design efforts. The 1969 storms resulted in the highest measured flows in recent decades in many Southern California streams, reaching about 8 times the average high flows. Major storms in 1950, 1955, 1986, 1997, and 2005 were focused more in Northern California, with New Years 1997 yielding 


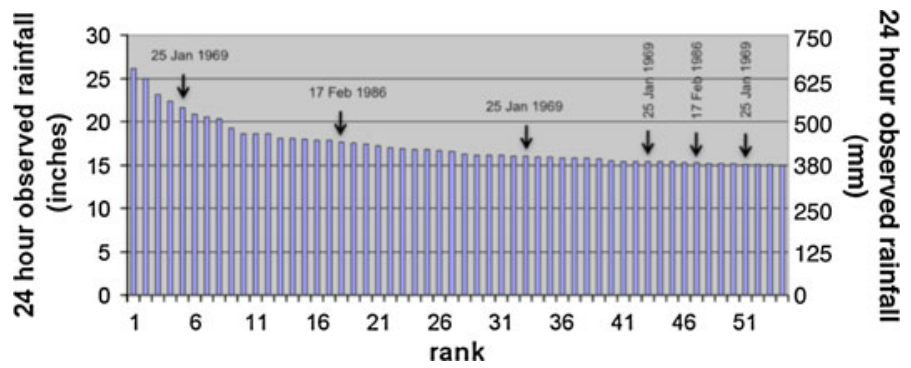

Fig. 2 Distribution of precipitation totals on 54 historical occasions when more than $380 \mathrm{~mm}$ ( 15 inches) of precipitation was recorded at stations in California, 1871-1998 (Jim Goodrich, former State Climatologist, written commun., 2008); six reports occurring on 25 January 1969 or 17 February 1986 are highlighted

the largest storm and floods in Northern California's modern era, and February 1986 also notable for its flooding. The floods of 1986 and 1997 were the largest recorded in the American River (at about 3 times the normal peak flow), and the 1986 flood was largest in the Russian River (at about twice the normal peak flow). Each of these three storms, and probably the 1862 storm, was fed by ARs that drew tropical and subtropical heat and moisture into California (Bao et al. 2006; Leung and Qian 2009).

\section{Scenario design}

In order to develop a storm scenario that is historically plausible, scientifically defensible, internally consistent (from place to place, and among the various meteorological variables to be considered), and suitably challenging for emergency-management agencies, a team of meteorologists, climatologists, hydrologists, and other scientists and engineers was convened. The team consisted of two groups, a design team of 11 scientists (of whom most are coauthors here) and a review team of four experts, along with three Multihazards Program scientists. The team met to develop strategy, and then reconvened 6 months later to review the resulting storm depiction. In the interim, the lead authors here developed historical analyses and simulations to complete the ARkStorm scenario.

Although motivated by the Noachian events of 1861-1862, the designers felt that it was critical that construction of the scenario rely on events that were sufficiently recent so that modern observations exist. Several of the most recent, large storms and floods are well known to emergency managers and have already been used for design of existing floodcontrol structures and emergency plans. Although many local agencies focus flood preparedness on specific (generally, recent) historic floods, established procedures exist for determination of "standard project floods and storms" or "probable maximum precipitation” (e.g., U.S. Army Corps of Engineers 1952, updated in 1965) based on historical rainfall-duration-area curves, extending to 5-days durations or less. The present study expanded on the data, science and models typically used, addressing a need to describe aspects of a major storm beyond just daily-level precipitation rates; in addition to large precipitation amounts, hazards posed by major storms include short-term rainfall intensities (which condition landslide risks), winds and barometric pressures (which determine coastal storm surges, wave heights and erosion), winds (for their direct structural damages), and precipitation forms (i.e., rain vs. snow). Because the scenario is intended to challenge emergency managers and to approach the scale and consequences of the 
extended megastorms of the 19th century, the recent storms needed to be "amplified." Nonetheless, in order to ensure maximum plausibility and defensibility, the project was reluctant to simply recapitulate precipitation extremes from "probable maximum precipitation" estimates or to simply specify a particular precipitation recurrence interval to be applied uniformly at every available weather station across the State. Furthermore, in the interests of scientific defensibility and internal consistency of the meteorological conditions as they evolved through the course of the scenario, it was deemed important to avoid arbitrary rescaling of the recent storm events. Rather than arbitrarily scaling up observed storm precipitation rates, a strategy of artificially concatenating historical episodeswithout directly modifying precipitation rates-was used to enhance the storms and challenges as needed. In doing so, the ARkStorm design draws upon recognition that sustained storms can yield remarkably large impacts without requiring improbable storm intensities.

Consequently, several components were concatenated (in time): First, a relatively wet autumn in much of the state was assumed to occur before the ARkStorm sequences, in order to precondition land surfaces to respond with rapid runoff to the ARkStorm events. Second, drawing upon the lessons from the floods of 1861-1862, the ARkStorm scenario was designed to have substantial impacts on both Southern and Northern California in rapid succession over the course of 23 challenging days, which is nonetheless still shorter than the month-long sequence of 1862. The statewide nature of ARkStorm impacts ensure that, even if local storm effects were within the capacity of individual emergency-management systems, potential problems arising from within-state competition for emergency resources could be realistically explored. For the ARkStorm, a major, historically large storm focused on (but not restricted to) Southern California was selected to begin the ARkStorm sequence. In order to ensure that the ARkStorm was more challenging in southern California than the particular historical Southern-California storm used, the AR feeding moisture to this storm was assumed to stall, during the day with maximum precipitation in the Transverse Range of Southern California, spending one more day over Southern California than in the historical sequence. Thus precipitation rates and winds were not specifically amplified, but the storm total was made substantially larger by increasing its duration. Based on observed behavior of many recent ARs, this artificially imposed stalling of the storm is plausible and realistic. Finally, soon after the storm focused in Southern California, the ARkStorm scenario entails a second large storm focused in Northern California. The wet autumn and early winter, together with the substantial precipitation from the first (more southern) storm, ensured that this second storm would yield even larger runoff and flooding in Northern California than occurred historically.

Thus the ARkStorm is a 23-day severe-storm scenario based on two major storm sequences from recent meteorological history, with an initial 10-day storm sequence focused mostly in Southern California followed, after a brief 5-day interlude during which the next storm sequence approached, by an 8-day storm sequence focused in Northern California. The Southern California phase is based on the storms of January 1969. Although this period was prior to the era of detailed satellite information, sufficient surface meteorological and streamflow data exist to provide excellent support for most of the ARkStorm design (with one notable exception to be discussed in Sect. 4.4). The autumn and early winter of 1968-1969 were 10-50\% wetter than normal in the central and northern parts of the state, so that-in order to minimize tampering with the historical record in the construction of the ARkStorm scenario - the actual historical weather prior to the major storms of January 1969 (i.e., 1 October 1968 thru 18 January 1969) was selected to provide the preconditioning period for ARkStorm. Thus, by designing the storm 
sequence to begin with the events of winter 1969, the stage was also set for strong flood responses in most of the state.

The ARkStorm scenario begins in earnest with the historical 19-27 January 1969 storms, a period of historically intense rains in Southern California, with considerable precipitation in much of the rest of the state as well. As discussed previously, in order to make this first, Southern California phase of ARkStorm more severe than history records, the storm was assumed to stall for an extra day on the day with peak precipitation in the Transverse Range of Southern California, 25 January. The measured Southern California precipitation on that day was so intense that it amounted to $30-40 \%$ of the entire (unusually wet) month's total.

The choice of a second storm for the ARkStorm sequence was less straightforward. The largest recent storms and floods in Northern California occurred around New Years Day 1997; however, Northern California also experienced memorable flooding in February 1986. Many criteria for choosing between these two candidate storms were discussed and considered, but the final decision was based on the problem of how to most plausibly join (meteorologically) the January 1969 storms end-to-end with one of these later storms. For the sake of plausibility, the (artificial) transition of atmospheric conditions from those at the end of the January 1969 storm to one of these later storms needed to be as natural and smooth as possible. Mean $500 \mathrm{hPa}$ geopotential heights (along with several other atmospheric fields) immediately before or after the various candidate dates for concatenating were considered in order to identify the most plausible transition dates between storms. Overall, meteorological conditions that were present four days prior to the start of the 1986 storm provided a more meteorologically plausible transition than did any other day before the 1986 storm or any day before the 1997 storm. Figure 3 illustrates the types of comparisons required for this decision, and shows how major synoptic features match reasonably well for concatenation of 27 January 1969 to 8 February 1986 conditions.

At the same time, the transition between storms needed to be short enough so that reservoir managers would be given the least plausible time to recover flood-control space completely from the first storm before the second storm arrived. A time window much longer than 5 days might allow reservoir operators to recover enough flood space to absorb the next storm's runoff. The 1986 storm began with heavy rain and high snow levels on 12 February, yielding significant hydrological impacts almost from the start. In contrast, the first several days of the 1997 storm, beginning on 26 December, were characterized by significant precipitation but comparatively cold conditions, yielding limited hydrologic impacts until later in the storm period. The heaviest rainfall and highest snow levels in this storm only began about 5 days later. Furthermore, daily precipitation totals $>380 \mathrm{~mm}$ were recorded in the 1986 storm (Fig. 2) but not in 1997, suggesting particularly high rainfall rates in the former.

Balancing these considerations, the decision was made to construct the ARkStorm from a hydrologic preconditioning period from 1 October 1968 to 18 January 1969, followed by an end-to-end concatenation of the January 1969 and February 1986 storms (as shown in Fig. 4).

\section{Implementation}

In order to provide other components of the Multihazards Project with the hourly temperatures, precipitation rates, wind speeds, and barometric pressures needed to estimate resulting hazards and damages, the scenario described above was simulated using a modern 


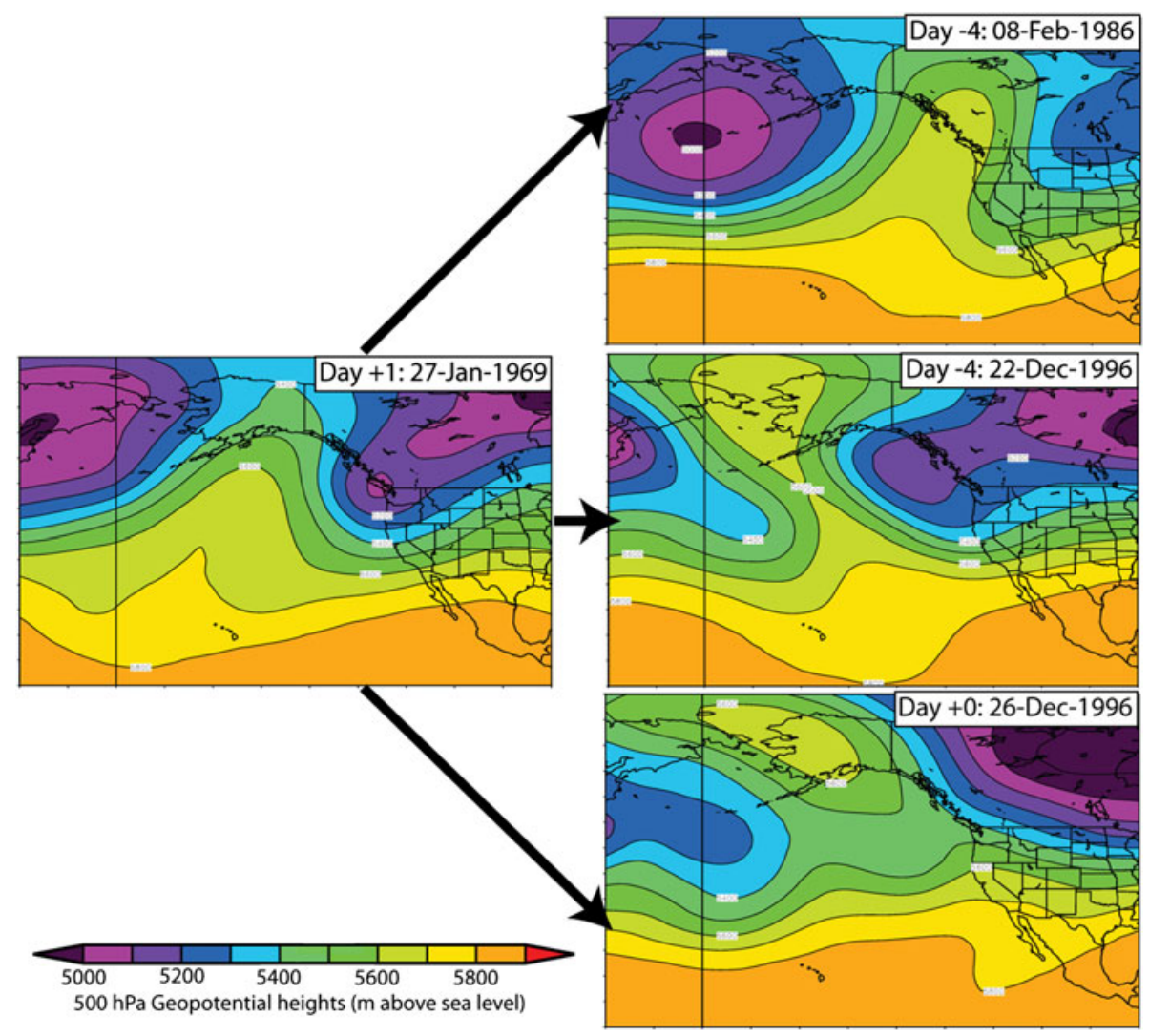

Fig. 3 Comparisons of $500 \mathrm{hPa}$ geopotential height (meters above sea level) on 27 January 1969 (day +1 following the termination of the January 1969 storm; left column) to possible transitional dates prior to the February 1986 storm (right column, top) and the December/January 1996/97 storm (right column, middle and bottom). Warm colors indicate higher heights (and pressures) and cool colors, lower

weather prediction model, with results tested for accuracy by comparisons with historical observations and for efficacy by simulating hydrologic responses with a macroscale hydrologic model of the state. The use of the full meteorological model ensured that the ARkStorm description is dynamically and geographically consistent, and temporally complete, which a simple compilation of meteorological observations could not provide.

\subsection{Meteorological simulations}

Meteorological conditions for the ARkStorm scenario were simulated with the Weather Research and Forecasting (WRF) model, version 3.0.1 (Skamarock et al. 2008). The simulation had four nested domains with horizontal resolutions of 2, 6, 18, and $54 \mathrm{~km}$. At 6- and 2-km resolutions (Fig. 5), all major mountain complexes in California are represented. The 2-, 6-, and 18-km gridded domains are interactively nested so that they both respond to influences from the larger grids and feed back to them. Each domain has 28 vertical levels, with highest resolutions in the lower troposphere. In the 18- and 54-km domains, the Kain-Fritsch (Kain 2004) cumulus parameterization scheme was used; in the 
PRECONDITIONING PERIOD

ARkStorm PERIOD

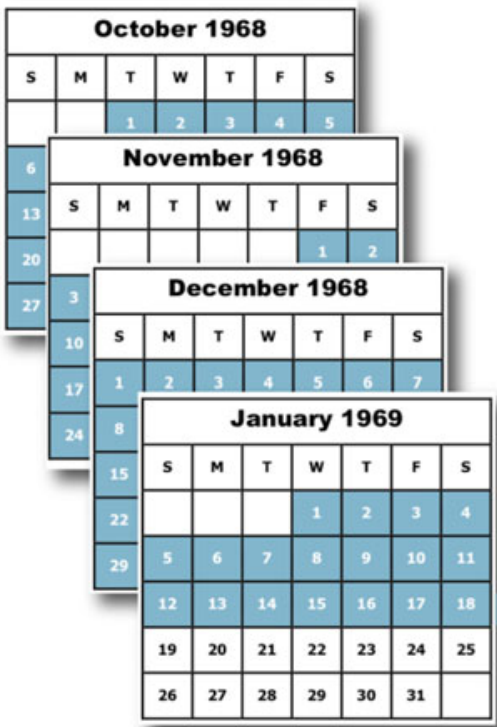

\begin{tabular}{|c|c|c|c|c|c|c|}
\hline \multicolumn{7}{|c|}{ January 1969} \\
\hline S & M & T & W & T & F & S \\
\hline & & & 1 & 2 & 3 & 4 \\
\hline 5 & 6 & 7 & 8 & 9 & 10 & 11 \\
\hline 12 & 13 & 14 & 15 & 16 & 17 & 18 \\
\hline 19 & 20 & 21 & 22 & 23 & 24 & 25 \\
\hline 26 & 27 & 28 & 29 & 30 & 31 & \\
\hline
\end{tabular}

Phase

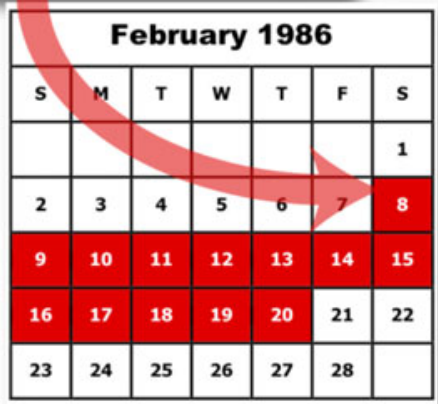

Northern

California

Phase

Fig. 4 Schematic depiction of the ARkStorm scenario story line, including hydrologic preconditioning period, southern California-focused January 1969 storm phase with repetition of the peak storm day of 25 January, and Northern California-focused February 1986 storm phase

6- and 2-km domains, only explicitly resolved convection is simulated. In all domains, the Yonsei University boundary layer scheme (Hong et al. 2006), similarity theory surface layer (Monin and Obukhov 1954), NOAH land surface model (Chen and Dudhia 2001), Lin microphysics (Chen and Sun 2002), rapid radiative transfer model longwave radiation (Mlawer et al. 1997), and Dudhia shortwave radiation (Dudhia 1989) parameterizations were used.

Boundary conditions for the WRF simulations were drawn from the global-scale National Centers for Environmental Prediction/National Center for Atmospheric Research Reanalysis Project (NNRP; Kistler et al. 2001; Kalnay et al. 1996) atmospheric data set. WRF was initialized every 5 days at 18 UTC and run for 5 days, $6 \mathrm{~h}$, with the first $6 \mathrm{~h}$ being discarded as model spin-up, a strategy previously used by Hughes et al. (2009) over Southern California. Interior boundary conditions were updated at each initialization, with the sea-surface temperatures and lateral boundary conditions updated continuously throughout the run.

The raw simulation data were then pieced together to form one continuous time series made up of the 19-27 January 1969 period, immediately followed by the 8-20 February 1986 period. Simulated conditions on 25 January, 1969 were repeated, hour-by-hour. Because it was discovered that simply holding the large-scale boundary conditions steady for an extra $24 \mathrm{~h}$ on 25 January 1969 did not prevent the AR from continuing its progress southward through Southern California, and thus did not result in the desired stalling of the storm (as discussed in Sect. 4.4), inclusion of the "extra" 25 January 1969 in the ARkStorm was eventually handled outside of these WRF simulations. To preserve the correct diurnal variations of surface temperature on this repeated day, a typical diurnal cycle was 


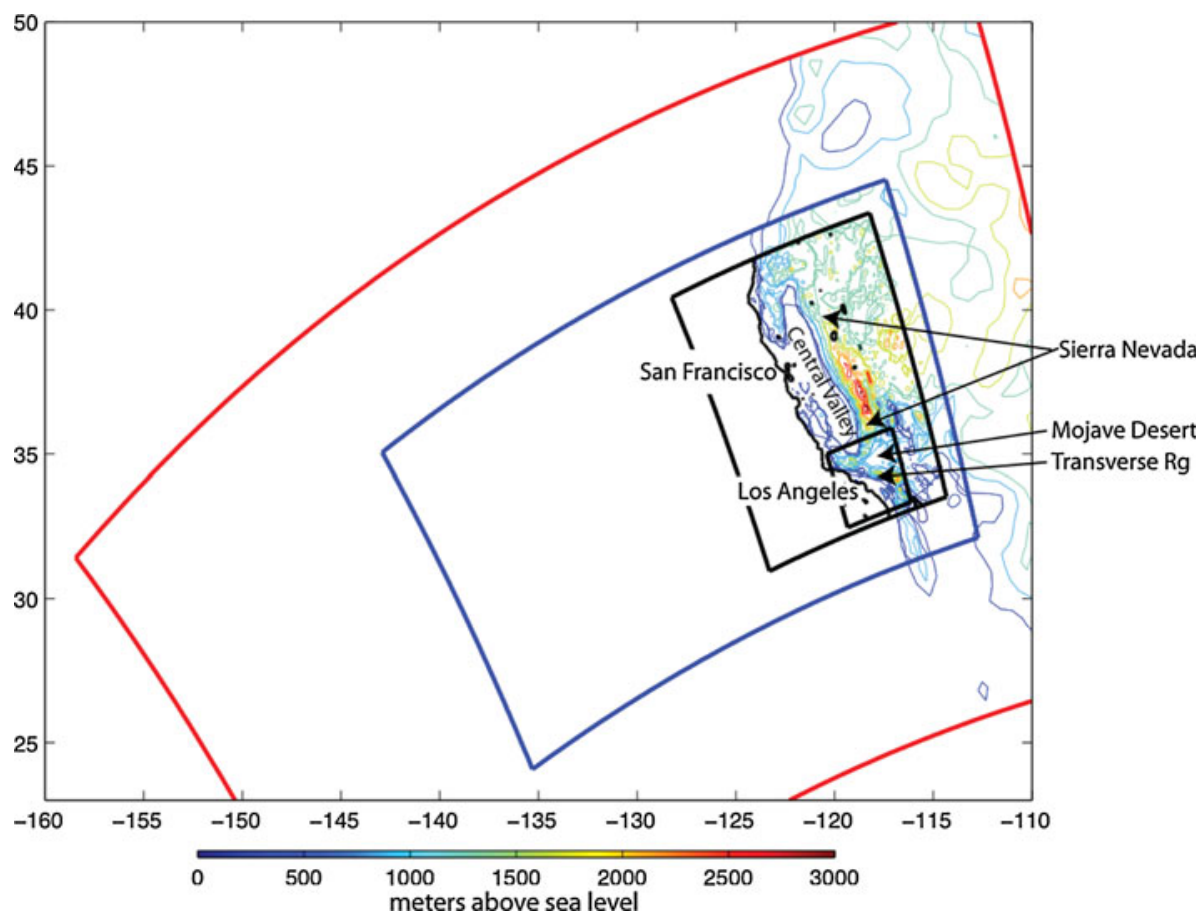

Fig. 5 Boundaries of nesting grids used in WRF model simulations; red for 54-km grid, blue for 18-km grid, larger black rectangle for $6-\mathrm{km}$ grid, and smaller black rectangle for $2-\mathrm{km}$ grid. Contours are topography (color bar, expressed in meters above sea level) mapped at finest resolution simulated at each location

identified from simulated temperatures for 24-26 January 1969, as the first principle component of the hourly values. This diurnal cycle was subtracted from the hourly temperatures simulated on 25 January. The residual for each hour of 25 January was then repeated hour-by-hour (00 UTC, 00 UTC, 01 UTC, 01 UTC, ..., 23 UTC, 23 UTC) and, then two copies of the diurnal cycle identified earlier were added back to impose two normal diurnal temperature cycles during the resulting 48-h-long 25 January episode. Similar principle-component analyses indicated that diurnal cycles of precipitation, pressure and wind variables were negligible, with any diurnal cycles being completely overwhelmed by synoptic changes associated with the storm. Therefore, those variables were simply repeated hour-by-hour to form a 48-h-long "slow" versions of 25 January 1969 conditions in the scenario. AR conditions have been observed to stall for 24-26 h, so that the 24-h stalling created here is entirely plausible.

The meteorological requirements of ARkStorm's other technical teams were used to define the WRF variables that were archived. Outputs provided (and still available for interested users) include hourly precipitation, 10-m winds, 2-m temperatures, water vapor, and sea level pressures.

\subsection{Hydrological simulations}

Simulations of runoff generation by a hydrologic model forced with the WRF-generated meteorology allowed evaluations of the efficacy of the storm-design strategy, the severity 
of WRF-generated storm conditions, and identification of problem areas where too little precipitation was simulated. The near-term Multihazards Program strategy was for resulting flood inundations to be hypothesized, initially, from semiquantitative linkages between WRF precipitation, simulated runoff rates, and Federal Emergency Management Agency floodplain maps to be followed, eventually, by more precise flood simulations using various operational flood-routing models at local and regional scales as models and willing partners become available. Only the former has been accomplished to date. Because it could be applied early on and repeatedly, the Variable Infiltration Capacity (VIC; Liang et al. 1994, model version 4.0.6) hydrologic model was applied as part of the efforts described herein to develop preliminary estimates of runoff responses to the WRFsimulated ARkStorm conditions. The VIC model was also used to estimate recurrence intervals for ARkStorm runoff rates and totals, as discussed in Sect. 5, to provide a basis for the semiquantitative inundations used in ARkStorm evaluations thus far (Porter et al. 2011).

VIC simulates (among other variables) daily runoff plus baseflow from grid cells on an 1/8-degree resolution over the conterminous U.S., although we focused here on California. VIC is driven by daily maximum and minimum temperatures, daily precipitation, and wind speeds on the same grid. In all VIC simulations here, wind speeds used as inputs are climatological values interpolated from NNRP data by Hamlet and Lettenmaier (2005). Temperatures and precipitation values for historical simulations were obtained from interpolated fields of daily observations (Hamlet and Lettenmaier 2005) or, for scenario simulations, were aggregated onto the VIC grid from the 6- and 2-km WRF outputs. VIC uses a tiled representation of the land surface within each model grid cell to allow for subgrid variability in topography, infiltration, and land surface vegetation classes (Maurer et al. 2002). Derived variables such as radiation, humidity, and pressure are simulated by the model based on the input precipitation, daily maximum and minimum temperature values using the algorithms of Kimball et al. (1997) and Thornton and Running (1999). Surface runoff is simulated with an infiltration formulation based on the Xinanjiang model (Wood et al. 1992), while baseflow follows the ARNO model (Liang et al. 1994; Sheffield et al. 2004). Soil parameters and vegetation cover were obtained from Andrew W. Wood of the 3 Tier Group, Seattle, and from the North American Land Data Assimilation System, respectively. Initial soil moisture conditions at the beginning of the 1969 ARkStorm period were derived from the 18 January 1969 output from a long VIC simulation of historical conditions beginning in 1916 and extending through September 2002 (a simulation that was also used to estimate ARkStorm-runoff recurrence intervals).

\subsection{Historical data}

Historical observations used in this study took several forms: First, as indicated previously, the WRF model simulations were nested within the global reanalyzed atmospheric fields from the NNRP (Kalnay et al. 1996) at each time step at the WRF boundaries and every 5 days in the interior of the WRF domain. A second set of historical weather observations used was the 12-km gridded interpolation of daily surface-air temperatures and precipitation over California river basins used to drive historical VIC simulations. This dataset is from Hamlet and Lettenmaier (2005), and represents a gridding of daily weather station observations that is informed by monthly fields from the PRISM dataset (Daly et al. 1994). Finally, ungridded daily precipitation-total and temperature reports from the historical Summary of the Day (NWS 1989 and updates thereto) database for cooperative weather stations in and around California were used for evaluation of the simulations, and were 
obtained from the National Climatic Data Center. Records from 435 cooperative weather stations were included in comparisons to WRF model results.

\subsection{Completing the scenario}

Initially, VIC was used to simulate runoff rates associated with a version of the gridded historical meteorological fields usually used to drive the model (Hamlet and Lettenmaier 2005) with historical storms concatenated according to the ARkStorm design. This simulation was compared to a simulation of the same historical days without the concatenations to test whether the ARkStorm design actually provided amplifications of runoff that were both plausible and challenging. Comparison of this initial simulation with the historical simulation indicated that daily peak and scenario-total runoff rates were doubled or more in much of the state (not shown).

Then, the WRF model was used to simulate the scenario. Initially, the WRF model was configured as in Sect. 4.1 except that the Morrison double-moment microphysics scheme (Morrison et al. 2009) was originally used and without the 2-km resolution nest over Southern California. In this configuration, simulated precipitation in the Transverse Range during the January 1969 storms was less than observed. When the WRF output was used to force the VIC hydrologic model, runoff from the Transverse Range was accordingly undersimulated relative to the historical VIC simulations. Thus the team faced a problem: The aim was to produce a challenging storm over Southern California, but WRF was not producing enough precipitation to match the January 1969 storm. Several modifications to the WRF model configuration were attempted, including adding the 2-km nest centered over the Transverse Range in hopes that higher topographic resolution would extract more precipitation from the model there. Adding the 2-km grid also offered advantages to other Multihazards Project teams, some of which were focused on Southern California and needed the highest possible resolution.

Upon close inspection, the AR that fed the WRF-simulated 1969 storm was found to be making its primary landfall $\sim 100 \mathrm{~km}$ too far south with this configuration, with precipitation forming only peripherally over the Transverse Ranges. We hypothesized that this problem was due to errors in the placement and configuration of the AR and its synopticscale environment in the large-scale NNRP fields, noting that 1969 was prior to the availability and therefore the assimilation of satellite data into the NNRP, a time when offshore meteorological observations were much less complete than in the satellite era.

A number of different model configurations were explored in attempts to correct the errors in this part of the storm simulation. Unexpectedly, the configuration change that allowed WRF to approximately capture observed precipitation patterns and rates from January 1969 was a change from representing cloud microphysics (processes associated with the formation and fall of cloud droplets and precipitation) in the model by the Morrison double-moment scheme versus using Lin microphysics. With Lin microphysics, precipitation is calculated differently from Morrison microphysics, and, as a result, latent heating of the atmosphere is different. We believe that, by chance, the change in heating was sufficient to cause the fronts, AR, and precipitation to evolve differently so that, in the simulation with Lin microphysics, the fronts and AR progressed southward more slowly, so that in simulations with the Lin microphysics the crucial AR made its landfall about $100 \mathrm{~km}$ farther north, in the Transverse Range, in much better agreement with historical events. Whether it be chance or dynamics, the purpose of the WRF simulation was to recreate a storm pattern like January 1969, and this particular simulation/realization 
provided the version that was needed for ARkStorm and thus was the simulation used thereafter.

In the process of solving the misplacement of the January 1969 AR in WRF, it was also determined that a simple repetition of the large-scale conditions on 25 January 1969 prior to downscaling by WRF did not produce the desired stalling of the storm. Doubling the duration of the large-scale boundary conditions for 25 January aggravated the problem of the poorly located AR landfall because it allowed even more time for the storm to migrate unrealistically southward. Given 24 more hours of the large-scale 25 January boundary conditions, the WRF-simulated AR did not stall for an extra day, but rather continued its within-region development, continuing southward. Because such AR stalling is realistic in some cases but did not occur in the actual 1969 storm or in WRF with an extra day of large-scale 25 January conditions imposed, the WRF outputs were postprocessed, hour by hour, to produce the desired stalling on 25 January, as a post-processing step after a WRF simulation-without the extra 25 January imposed-was completed, as described in Sect. 4.1.

\section{Results}

Some of the important extremes resulting from the simulations of the ARkStorm scenario are summarized in Fig. 6. High winds in coastal and inland areas, large precipitation totals in both Northern and Southern California, and substantial runoff generation in the Sierra Nevada and mountains of Southern California form the core challenges from an ARkStorm sequence. These storm conditions and their meteorological and hydrological underpinnings of the scenario are detailed in this section.

The large-scale, historical evolution of the ARkStorm meteorology is illustrated in part in Figs. 7 and 8 by the NNRP-derived 500 and $925 \mathrm{hPa}$ geopotential height analyses for the scenario periods based on 19-27 January 1969 (scenario days 1-10; Fig. 7) and 12-20 February 1986 (days 15-23; Fig. 8). During the first period, at mid-tropospheric levels about $5 \mathrm{~km}$ above sea level, an extended period of onshore flow crossed California from over the subtropics. A low-pressure storm center formed north of Hawaii by 21 January, and then migrated eastward and joined with a low-pressure trough over southwestern Canada on 25 January. Two days later, the trough pushed southeastward and severed the Pacific storm track, cutting California off temporarily from the arrival of more storms. Near the surface, at $925 \mathrm{hPa}$, two distinct storm centers reached the West Coast between 19 and 27 January. The first made landfall in Northern California from 19 to 21 January, with strong southwesterly flow impacting the southern half of the state. After a brief lull on 23 January, a second storm center came ashore in the Pacific Northwest on 25-27 January, with another period of strong southwesterly flow crossing into Southern California, especially on 25 January. Circulations during the second scenario period, based on February 1986, were qualitatively similar to its predecessor, albeit shifted farther to the north. Strong onshore flow crossed California at $500 \mathrm{hPa}$ from over the subtropical Pacific flowing south of a high-pressure ridge centered over Alaska. At $925 \mathrm{hPa}$, two well-defined storm centers made landfall in the Pacific Northwest and southwestern Canada, while strong southwesterly flows slammed into the northern half of California. The strong southwesterly flow on 17 February coincided with the peak precipitation in the February period.

The WRF simulation captures the essential details of the ARkStorm in January 1969 and February 1986. Figure 9 shows WRF-simulated patterns of vertically integrated 


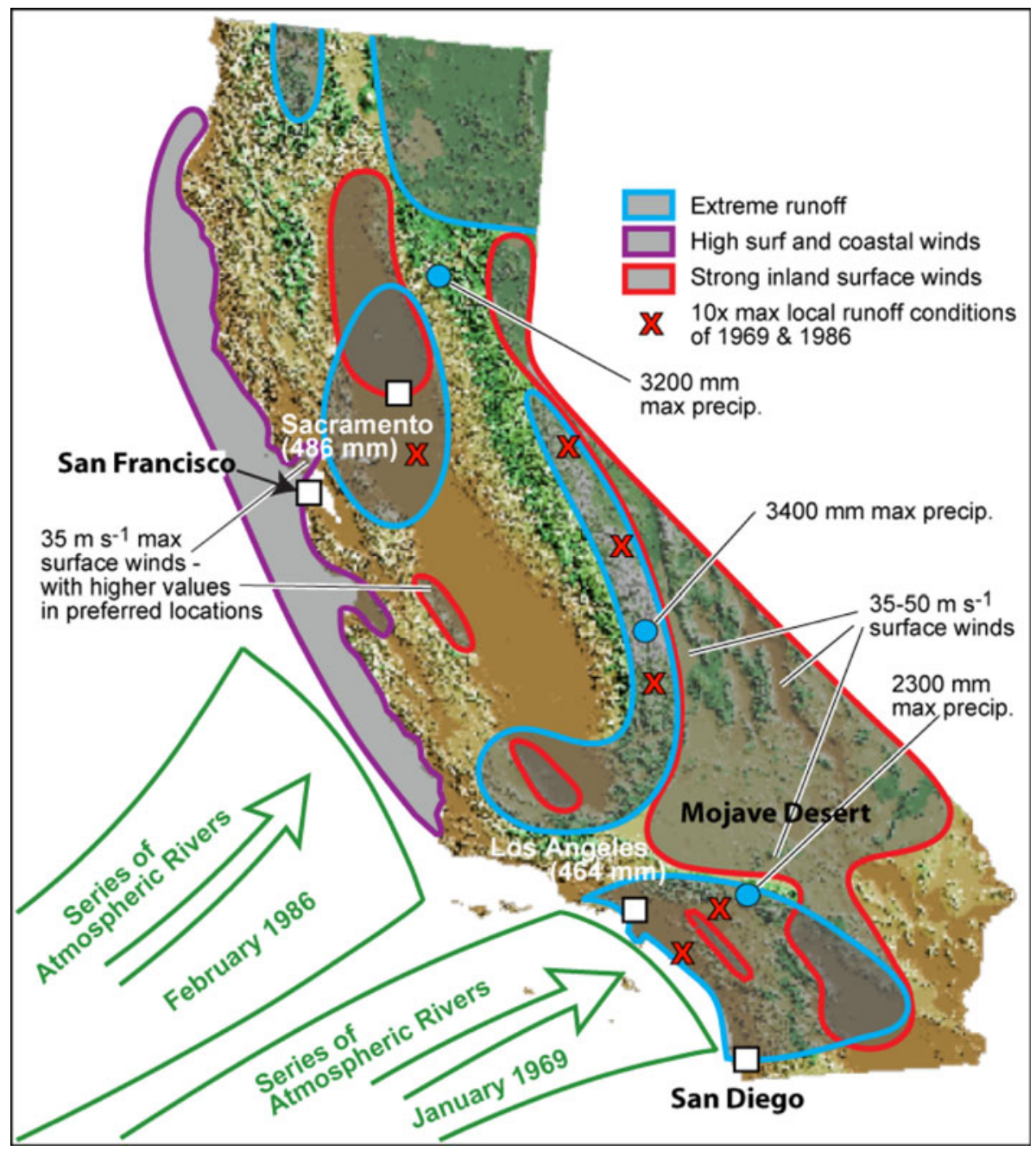

Fig. 6 Summary map of some extreme weather conditions resulting from the ARkStorm scenario

horizontal water vapor transport on selected days. During the 3-day period that ended with extreme precipitation on 25 January 1969, a narrow, intense plume of strong water vapor transport directly impacted Southern California's Transverse Ranges from the southwest. The onset of the February 1986 period of storminess (i.e., 12-14 February) was also accompanied by the landfall of a narrow, intense vapor-transport plume, albeit farther north in Central California's coast ranges and the Sierra Nevada. These vapor-transport plumes were fed by intense ARs originating in the subtropics. The AR of 12-14 February eventually tracked southward, impacting Southern California in a weakened state. Another AR - the last in the ARkStorm sequence-made landfall over Central California with heavy precipitation on 17 February 1986.

Daily (and half-monthly in the preconditioning period) precipitation totals from observations and the WRF simulation are shown in Fig. 10 for three locations. In the upper 

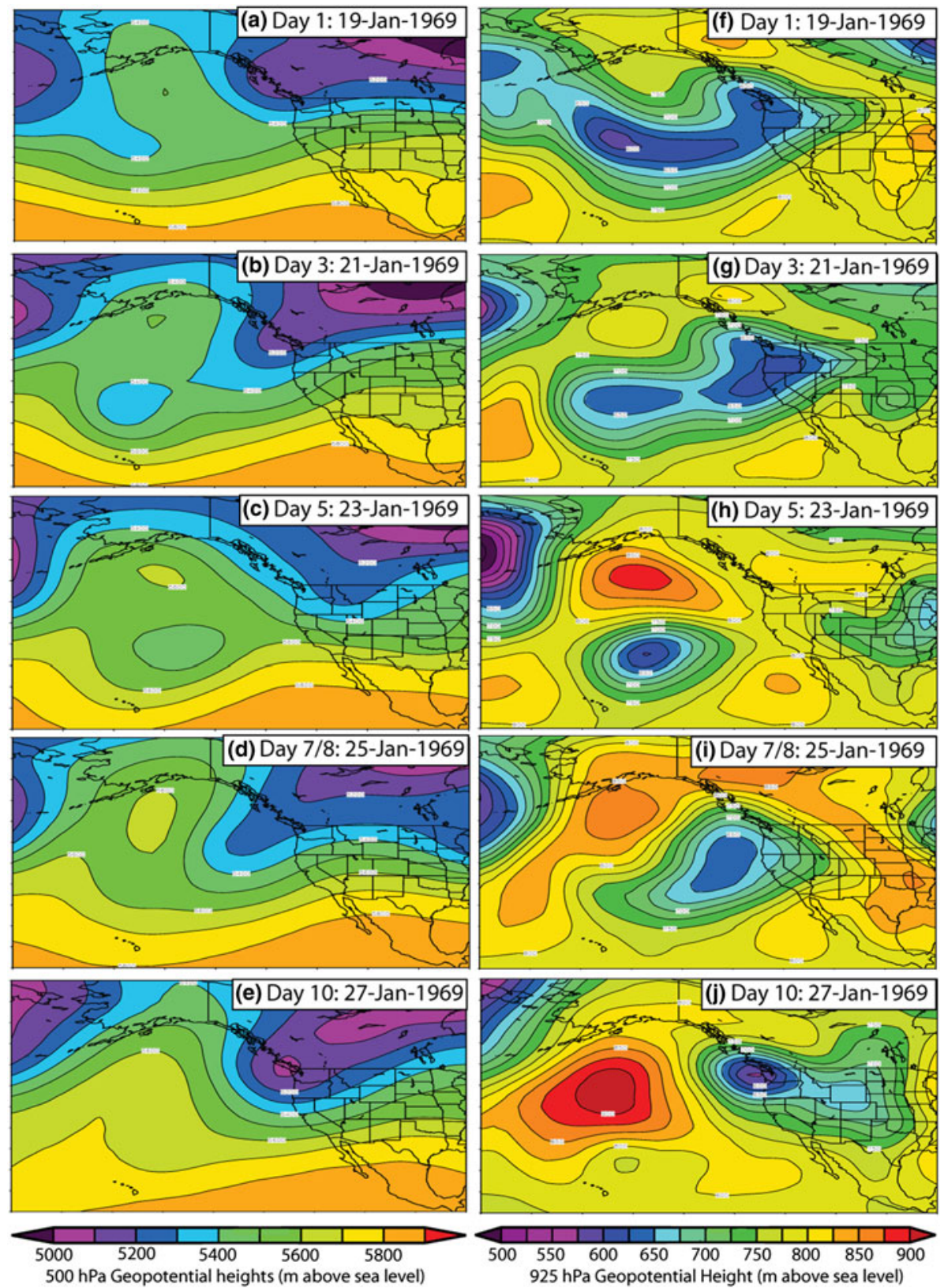

Fig. 7 Daily NNRP 500 (left) and $925 \mathrm{hPa}$ (right) geopotential heights for days 1-10 of the ARkStorm scenario between 19 and 27 January 1969. Every other day is shown; low heights (and pressures) are indicated by cool colors and high heights (and pressures) by warm colors

panel, a Sierra Nevada site at $\sim 1,600 \mathrm{~m}$ above sea level, WRF undersimulates precipitation during the Southern California phase and oversimulates precipitation during the Northern California phase. In the two lower panels, corresponding to neighboring sites in 

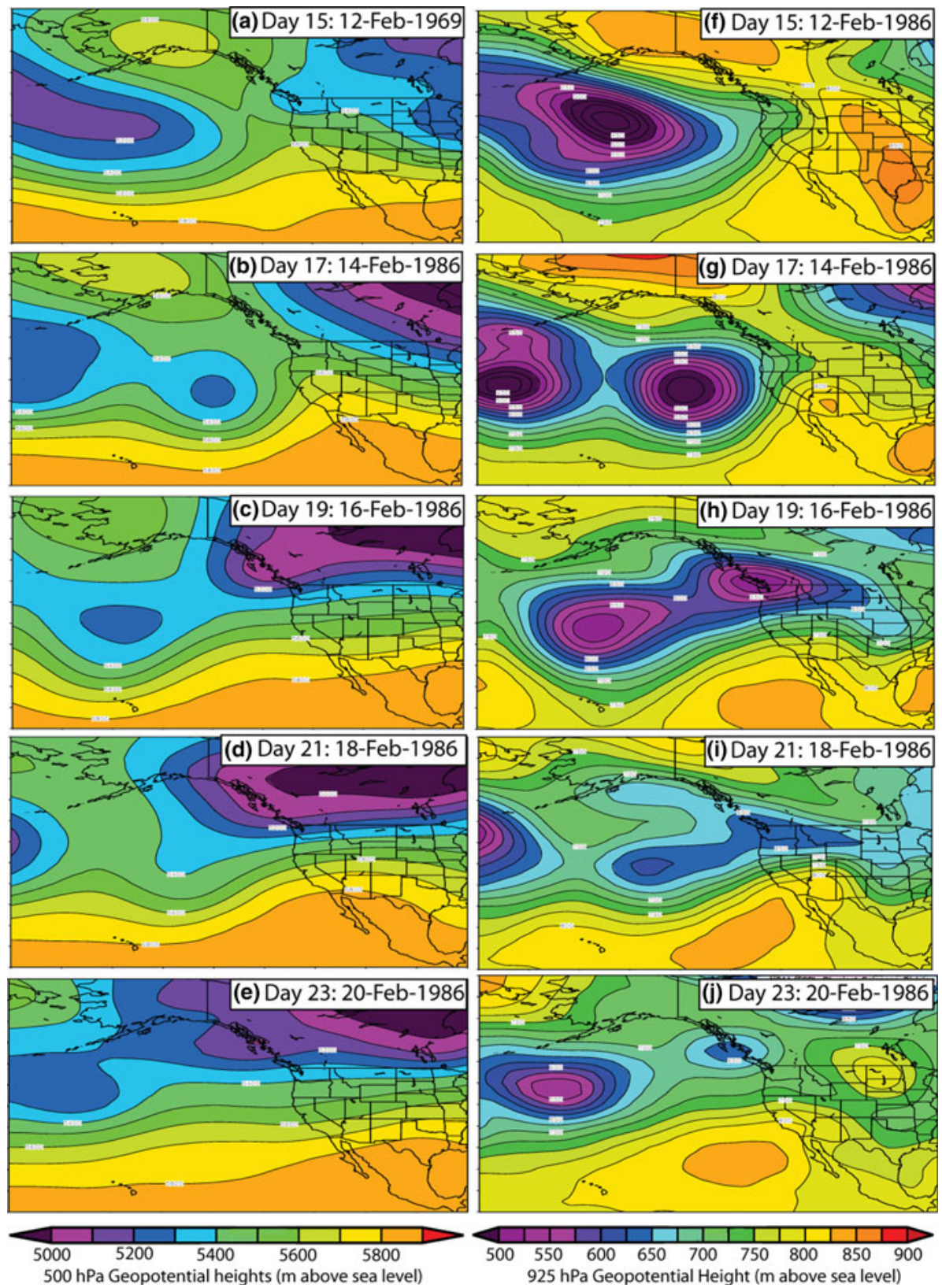

Fig. 8 Daily NNRP 500 (left) and $925 \mathrm{hPa}($ right) geopotential heights for days 15-23 of the ARkStorm scenario between 12 and 20 February 1986. Every other day is shown and color scheme is as in Fig. 7

the San Bernardino Mountains at 850 and 1,600 m above sea level, respectively, precipitation totals during the Southern California phase of the storm sequence are undersimulated at the lower site and well simulated at the upper site. Overall, the Sierra Nevadan locale received $1,000 \mathrm{~mm}$ of precipitation in observations and almost $1,300 \mathrm{~mm}$ in the 

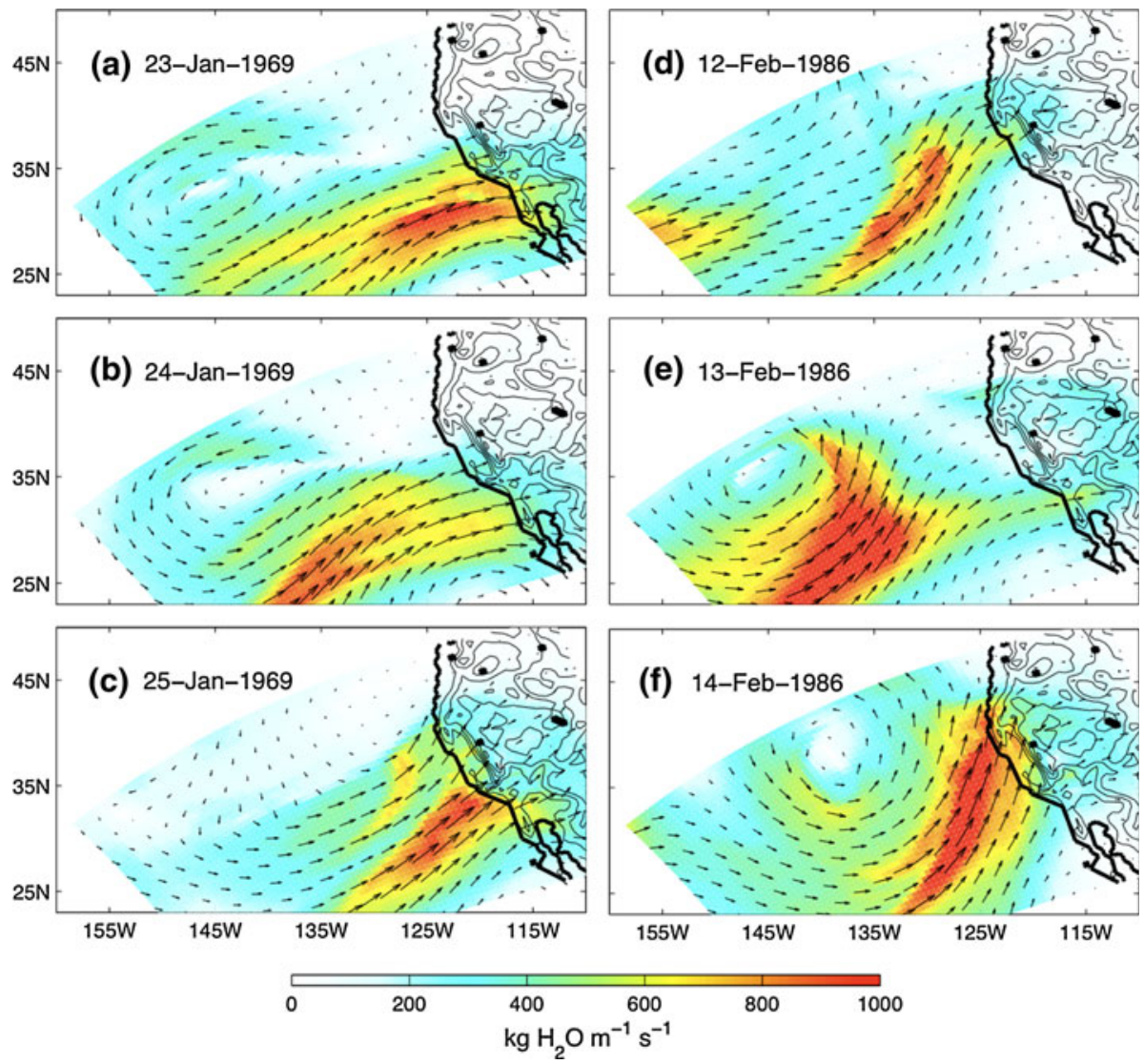

Fig. 9 Example sequences of WRF-simulated instantaneous maps of integrated water-vapor transports (IVT; $\mathrm{kg} \mathrm{m}^{-1} \mathrm{~s}^{-1}$ ) showing the general configuration of atmospheric rivers, at 12 UTC each day, immediately preceding and during peak-precipitation periods of the ARkStorm scenario as simulated by the WRF model: a 23 January 1969; b 24 January 1969; c 25 January 1969; d 12 February 1986; e 13 February 1986); f 14 February 1986. Colors indicate intensity of transport (see color bar at bottom), and vectors indicate transport directions

6-km WRF nesting. At the lower southern site, almost $1,900 \mathrm{~mm}$ of precipitation was observed, and WRF simulated about 1,700 $\mathrm{mm}$ in its 6-km nesting and about 1,250 $\mathrm{mm}$ in its $2-\mathrm{km}$ nesting. At the higher southern site, the 2-km WRF nesting received somewhat over 2,000 $\mathrm{mm}$ of precipitation compared to observed totals of about 1,800 $\mathrm{mm}$. The 5-day lull between the January 1969 and February 1986 components of the scenario is visible in Fig. 10, as are the major storm peaks on 25 January and 14-17 February.

Simulated precipitation totals are mapped for the 6-km and 2-km WRF grids in Fig. 11a, b. Broad areas of the southern and central Sierra Nevada receive over $2 \mathrm{~m}$ of precipitation during the scenario, with accumulations accruing from both the January 1969 and February 1986 storm periods. Similar precipitation totals accumulate in the ranges to the north and east of Los Angeles, from the January 1969 storm period. These ARkStorm precipitation totals greatly exceed the National Weather Service's Hydrometeorological Design Studies Center partial-duration estimates (Perica et al. 2011) of 100-year monthly precipitation in broad areas of the Northern and Southern Sierra Nevada, and approach or 


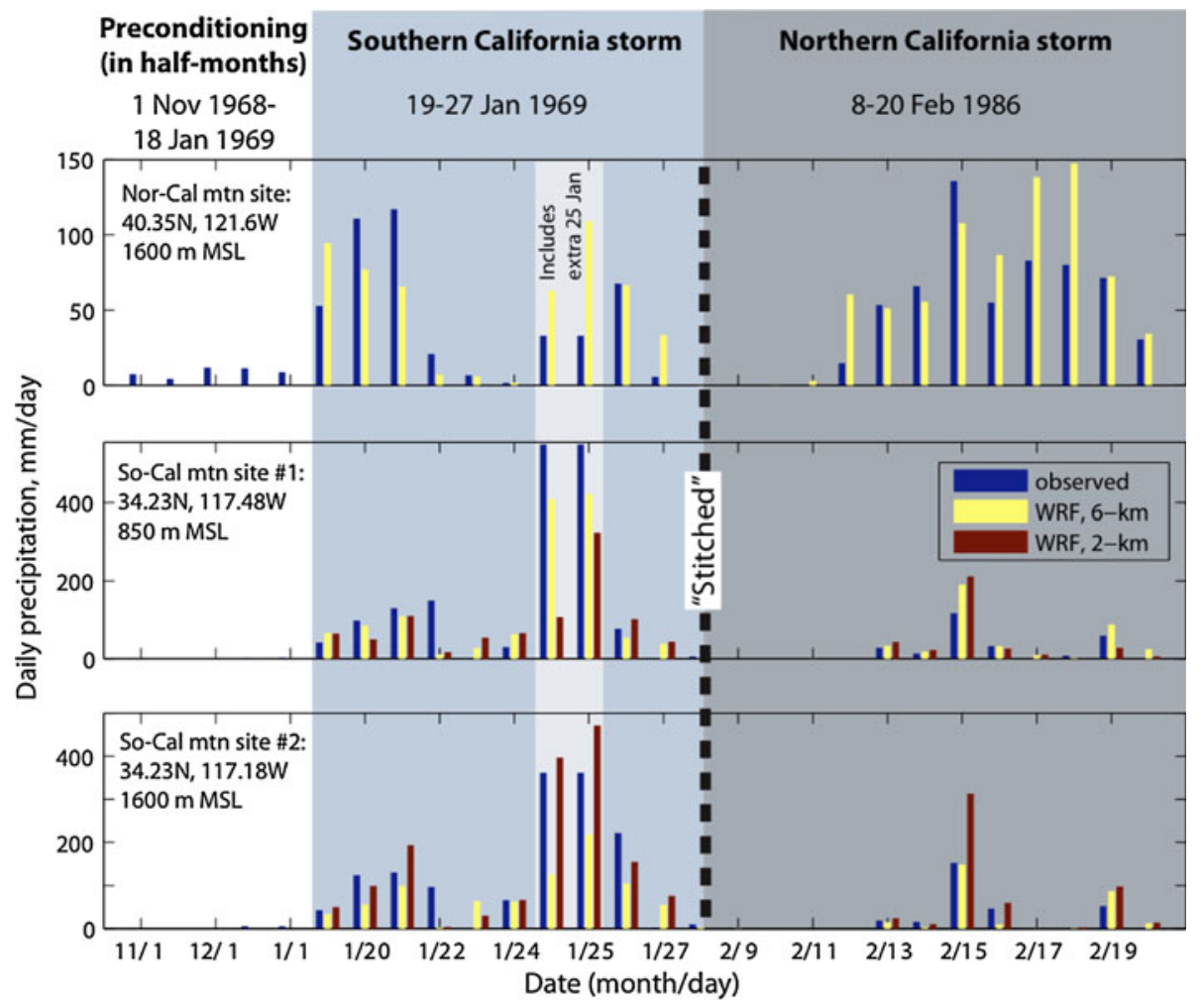

Fig. 10 Daily precipitation totals during ARkStorm period (with half-monthly totals shown during preconditioning period) at three locations in California from observations (indicated by three white $x$ 's in Fig. 11), the 6-km WRF nesting and the 2-km WRF nesting, with concatenations (dashed line) and repetition of 25 January 1969. White, blue, and gray shading corresponds to: preconditioning, Southern California storm track on 19-27 January 1969, and Northern California storm track on 8-20 February 1986 phases of ARkStorm scenario

equal 100-year monthly levels in the mountains of Southern California. Maximum hourly precipitation intensities (not shown) approaching $50 \mathrm{~mm} / \mathrm{h}$ are simulated in the Transverse Range north of Los Angeles. Maximum precipitation rates in the Sierra are mostly lower than in Southern California but reach $40 \mathrm{~mm} / \mathrm{h}$ on some windward slopes. These peak hourly precipitation totals approach 100-year levels locally in the Sierra Nevada but mostly are closer to 50-year levels in the mountains of the State (Perica et al. 2011). Maximum daily precipitation totals (not shown) in Southern California approached $700 \mathrm{~mm}$ (27 in) and $300 \mathrm{~mm}$ (11 in) in the Sierra Nevada; thus maximum daily ARkStorm totals were smaller than probable-maximum precipitation estimates from the National Weather Services's Hydrometeorological Design Studies Center (Corrigan et al. 1999) by at least $250-500 \mathrm{~mm}$ (10 to $20 \mathrm{in}$ ) everywhere in the state and are closer to the estimated 100-year daily precipitation totals (Perica et al. 2011).

Observed precipitation totals from several hundred stations are compared to WRFsimulated totals in Fig. 11c, indicating good agreement between observed and simulated precipitation for stations that received lower- to midrange totals. Stations that received the largest precipitation totals tend to have been overestimated by WRF, with most of these 

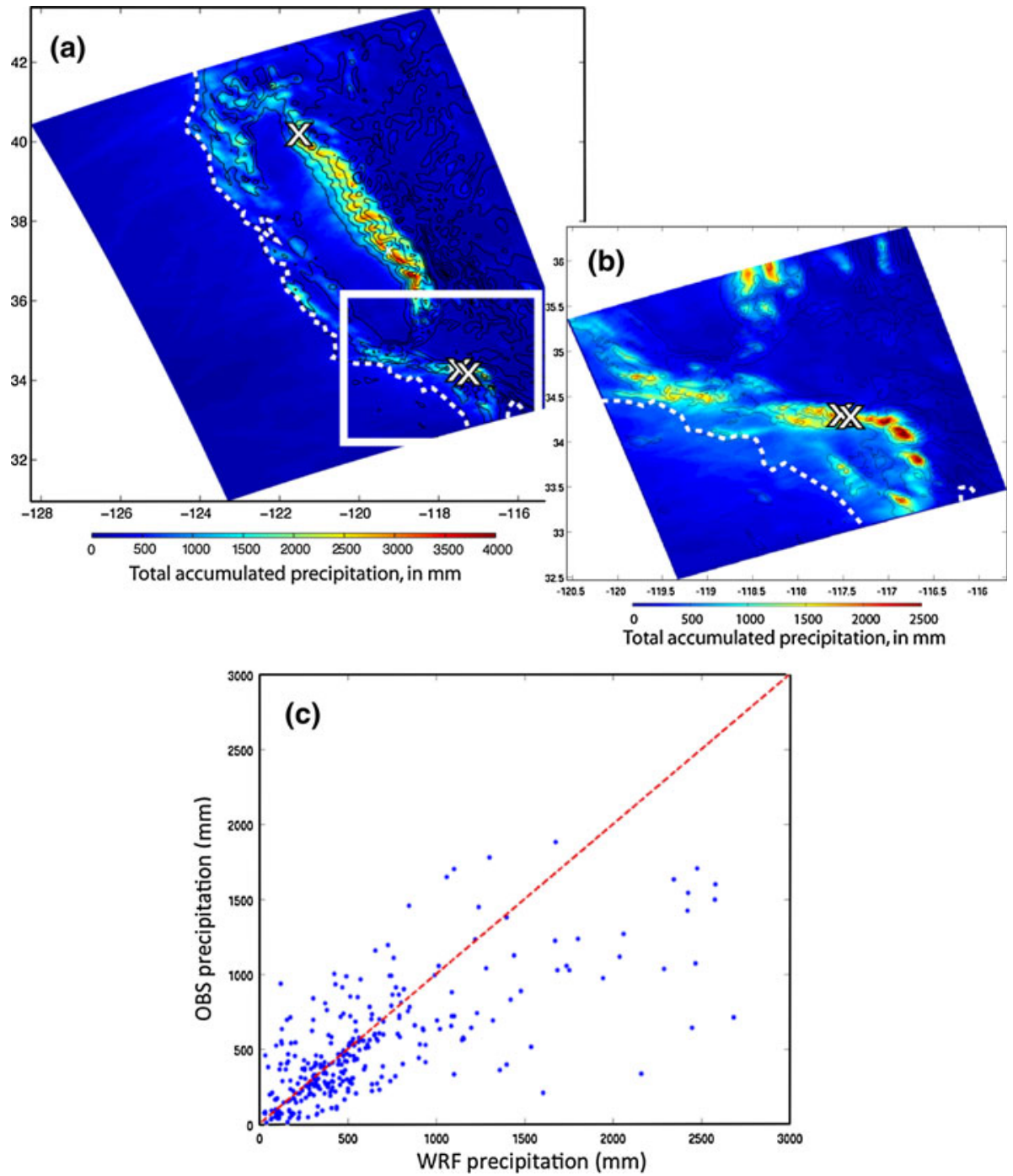

Fig. 11 WRF-simulated precipitation totals during the ARkStorm scenario in a 6-km, and b 2-km grid nestings, and c simulated versus observed precipitation at cooperative stations in the 6-km WRF domain. The white box in a is the location of the 2-km grid nesting; the dashed white curves in $\mathbf{a}$ and $\mathbf{b}$ are coastline; the white x's in $\mathbf{a}$ and $\mathbf{b}$ are locations of the time series in Fig. 9; and the red dashed line in $\mathbf{c}$ shows perfect agreement $(1: 1)$

stations located in the western Sierra Nevada. The WRF-simulated precipitation totals there are significantly larger than the historical totals, further ensuring that the ARkStorm scenario is a true megastorm by historical standards.

Temperatures during the ARkStorm scenario are, on average, above freezing throughout California, except for the highest parts of the Sierra Nevada. Sub-freezing temperatures were most widespread in the Sierra Nevada for several days prior to the 25 January 1969 storm peak and during the lull between the January 1969 and February 1986 components of 
the scenario. Temperatures in the mountains in Southern California dipped below freezing at night during the lull, but otherwise were well above freezing. This ensures that most of the intense precipitation at these altitudes fell as rain rather than snow. Figure 12 shows the amount of time with temperatures below freezing across the 6-km WRF domain. With these generally warm temperatures, only the highest reaches of the Sierra Nevada received much snow from the ARkStorm, and indeed, a map of areas where snowpacks were enhanced in ArkStorm (not shown) only highlights the red and black areas in Fig. 12. Given the wet soils and sustained precipitation during ARkStorm, much of the copious rainfall would have run off rapidly, causing flooding, landslides, and debris flows.

Winds are another source of damages and disruption during west coast storms. The maximum-hourly ARkStorm surface winds are very intense $(\sim 30 \mathrm{~m} / \mathrm{s})$ along the northern California coastline, near the ridgelines of the mountains east of Los Angeles and in the southern Sierra Nevada (Fig. 13). Wind gusts greater than about $30 \mathrm{~m} / \mathrm{s}$ are generally considered extreme and dangerous in California, and winds greater than about $15 \mathrm{~m} / \mathrm{s}$ typically result in high-wind advisories and potential structural damages. Most of the simulated peak winds occurred during the February 1986 phase of the storm sequence. High winds also were simulated in the high Mojave Desert, with peaks occurring there mostly in the January 1969 phase. The northern parts of the Central Valley experienced fairly strong winds during both phases. The simulated winds presented in Fig. 13 are actually weaker than the peak gusts that would have occurred in nature due to the spatial and temporal smoothing of wind fields inherent in the spatially discretized and hourly averaged WRF simulations.

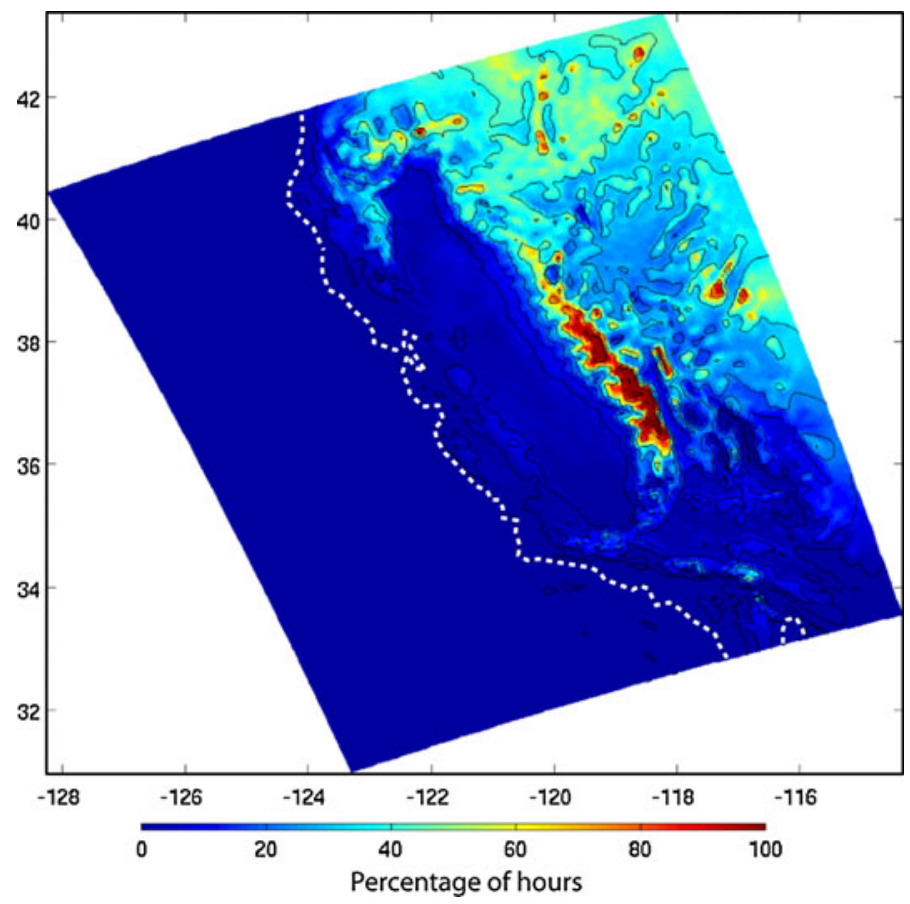

Fig. 12 Simulated percentage of scenario hours below freezing $2 \mathrm{~m}$ above surface; white dashed line is coastline 


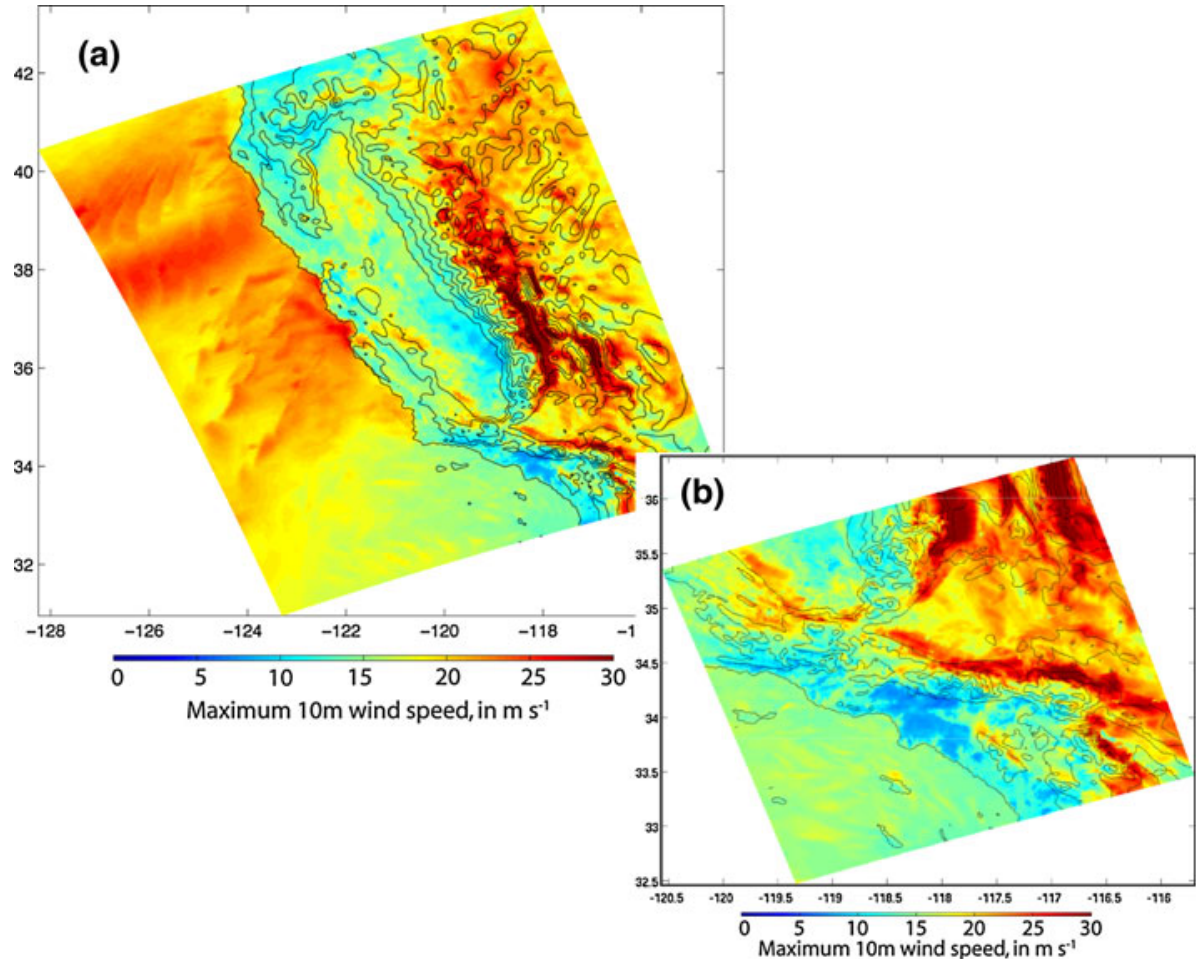

Fig. 13 Maximum WRF-simulated wind speed 10-m above surface during the ARkStorm scenario within the a 6-km WRF nest in and $\mathbf{b} 2-\mathrm{km}$ WRF nest

The hourly WRF-simulated temperatures and precipitation rates were combined into daily values, aggregated onto the 12-km VIC grid, and used to force the VIC hydrologic model. Simulated ARkStorm runoff totals and peak runoff rates are compared to those simulated when the VIC model is forced by strictly historical conditions (spanning the same days as in ARkStorm, but with no repetitions or concatenations, and based on historical meteorology) in Fig. 14a, b. Total runoff from the central and southern Sierra Nevada is particularly enhanced ( $>10$ times larger than their historical counterparts), as are daily peak runoff rates in the Sierra Nevada and in Southern California mountains. More broadly, daily peak runoff rates are 3-5 times greater than historical in much of the coastal plains of Southern California and the Central Valley. Runoff generation was somewhat undersimulated in coastal mountains north of San Francisco and farther south along the central California coast, as well as in the lee of the southern Sierra Nevada and mountains of Southern California.

Finally, ARkStorm-simulated runoff rates were compared to a long VIC simulation of historical conditions from October 1916 thru September 2002, to estimate recurrence intervals for maximum 3-day, maximum 7-day, and scenario-long runoff totals resulting from ARkStorm, with the 3-day recurrence intervals mapped in Fig. 14c. In these comparisons of unrouted VIC-simulated runoff rates, the extreme events generated in response to ARkStorm range from 50 to 100 year events in most mountain headwaters of southern, central, and (some) northern California river basins, to 500- to greater than 1,000-year events in areas around Los Angeles, in the central and southern Sierra Nevada, and in the 
(a)Change in Peak Daily Runoff Simulated

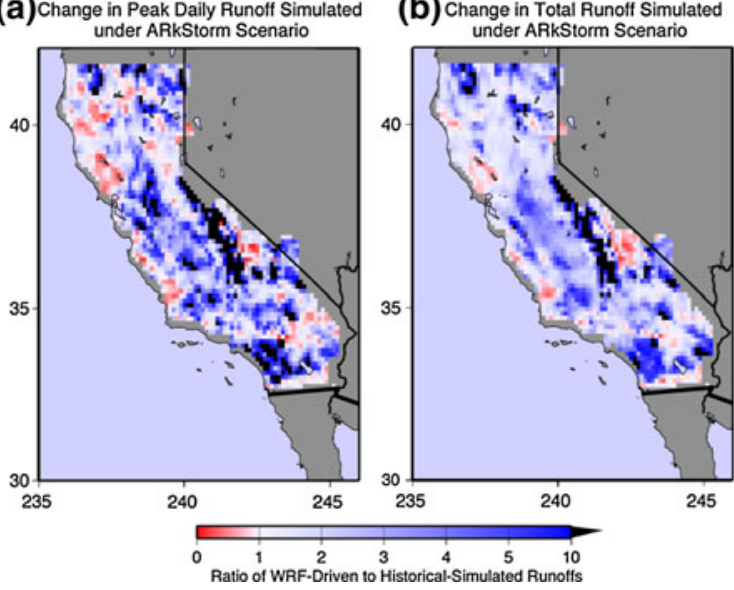

(C) Recurrence Intervals of Maximum 3-day Runoff (relative to WY1916-2003 Historical Simulation)

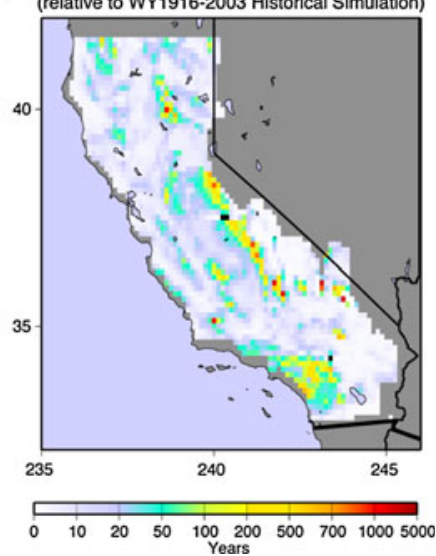

Fig. 14 a, b Simulated ratios of runoff -plus-baseflow rates from VIC hydrologic model forced by WRFsimulated ARkStorm daily meteorology and driven by historical meteorology, as a peak daily flows, b total flows, and c estimated recurrence intervals of 3-day totals of runoff, compared to a historical VIC-simulation of 1916-2003 hydrologic conditions. Meteorological inputs to the VIC simulations shown were at each VIC grid cell derived from the highest-resolution WRF results available by combining hourlies into daily meteorology and aggregating WRF grid-cell values into (larger) VIC grid-cell averages

Feather River basin of Northern California. From these runoff-generation frequencies and current 100- and 500-year floodplain maps, ARkStorm flood inundations were roughly estimated (Porter et al. 2011) and used in interviews with emergency and resource managers.

\section{Summary and discussion}

The USGS Multihazards Demonstration Project is working with a large number of science-, resource-, and emergency-management agencies to develop and explore an emergencypreparedness scenario in which an especially severe winter storm impacts California. The scenario has been designed to be more extreme than the typical "storms of record" or "floods of record" that many emergency-preparedness plans use but has been designed to emphasize scientific and historical plausibility. Rather than simply trying to recreate the largely unknown storm conditions that applied during the largest known flood episode in California in 1862, or arbitrarily scaling up one of the more recent, more adequately monitored historical storms, a strategy based on plausible sequencing of recent, large storms was developed.

The scenario constructed is based on a rapid sequencing of winter storms from January 1969 and February 1986 separated in this hypothetical storm scenario by only about 5 days, with the primary focus of the former (latter) being in Southern (Northern) California. The outcomes of this hypothetical sequence of storms were reconstructed by a numerical simulation of the local results of weather conditions described by the global NNRP data sets. The rapid storm sequencing exacerbates flooding by depositing rain on already saturated surfaces and by reducing the time available for water managers to prepare flood-control facilities for later storms. The design also assumed that one of the storms 
stalls over Southern California, enhancing rainfall totals and flooding there. Because of these elements, the scenario describes a storm sequence that is more catastrophic than either of the major historical storms that went into it. The result was a wide range of severe storm conditions summarized previously in Fig. 6: High surf and strong winds would batter the coastal zone from northwest of Los Angeles to near the Oregon border. Broad areas with extreme runoff also resulted from intense and warm rains falling at high altitudes, especially in the Sierra Nevada and across the southern mountain ranges. Finally, large areas suffer strong surface winds $\left(35-50 \mathrm{~m} \mathrm{~s}^{-1}\right)$ in the scenario.

In designing ARkStorm, care was taken to avoid creating an implausibly severe storm: The Southern California phase of the storm sequence was only stalled for a single day; the Northern California phase was not stalled at all. A full 5-day lull was left between the southern and northern phases of the storm sequence, so that 12 days separated the storm peaks in Southern and Northern California, as in 1862. Temperatures during the storms were not increased above historical temperatures to reflect projections of a warming world. Nonetheless, the storms were warm storms, yielding extreme precipitation and high snow levels. Using cooler historical storms might have reduced the precipitation and flooding, but also could have allowed for conditions suitable for other storm impacts, such as tornadoes and hailstorms. Finally, the scenario does not explicitly hypothesize widespread fires prior to the storms, which would have increased chances for debris flows and flash flooding.

Unlike the first hazard scenario that the Multihazards Project addressed (an earthquake disaster scenario), the ARkStorm scenario requires that an important new elementforecasting - be addressed. Earthquakes happen unexpectedly and their consequences follow thereafter. Storms, and especially the flooding that they cause, are typically forecasted (with varying accuracy) at lead times of a few days or more. Most flood managers make preparatory decisions during, and in immediate advance of, an approaching storm and in light of modern forecast systems, these decisions depend as much on forecasts as on the actual events at the time of the decisions. These decisions affect the distribution and timing of floods, ameliorating them when possible but, even when amelioration fails, modifying the floods nonetheless. Thus, the ARkStorm scenario as described here is only a first step for the Multihazards Project. Next steps will include developing realistic forecasts of the meteorological events and estimation of plausible flooding outcomes. The forecasts can then be provided to expert flood managers from selected river basins so that they can even better explore effects of an ARkStorm.

The storm scenario (Fig. 6) was designed to be larger overall than the largest 20th century events in both Northern and Southern California. Nonetheless, it probably is not as large as the largest observed storm, that of the winter of 1862. Furthermore, recent analyses of AR conditions represented in an ensemble of climate-change projections from the Intergovernmental Panel on Climate Change's Fourth Assessment suggest that larger-thanhistorical AR storms in California might become more common in a warming world (Dettinger 2011). If these projections and analyses prove correct, storm sequences like the ARkStorm scenario may become more likely as the century progresses, but even without such change, history indicates that an ARkStorm could occur in almost any winter.

Acknowledgments Thanks to Andrew W. Wood, Alan F. Hamlet, Dennis Lettenmaier, for VIC model, forcings, and parameters. The Delta Science Program's postdoctoral fellowship provided partial salary support for TD, and support for $\mathrm{MH}$ was received from a National Research Council postdoctoral award at NOAA and the USGS Multihazards Program. 
Open Access This article is distributed under the terms of the Creative Commons Attribution Noncommercial License which permits any noncommercial use, distribution, and reproduction in any medium, provided the original author(s) and source are credited.

\section{References}

Bao J-W, Michelson SA, Neiman PJ, Ralph FM, Wilczak JM (2006) Interpretation of enhanced integrated water vapor bands associated with extratropical cyclones: their formation and connection to tropical moisture. Mon Wea Rev 134:1063-1080

California Department of Water Resources (DWR) (2005) Flood warnings-responding to California's flood crisis. California DWR report, p 21. Accessed, 22 July 2009, http://bondaccountability. resources.ca.gov/Attachments/ b1a801cb-36af-44c7-854e-3b9047a4525f/24/01-10-05flood_warnings.pdf

Chen F, Dudhia J (2001) Coupling an advanced land-surface/ hydrology model with the Penn State/ NCAR MM5 modeling system. Part I: model description and implementation. Mon Wea Rev 129:569-585

Chen S-H, Sun W-Y (2002) A one-dimensional time dependent cloud model. J Meteor Soc Japan 80:99-118

Corrigan P, Fenn DD, Kluck DR, Vogel JL (1999) Probable maximum precipitation for California. National Oceanic and Atmospheric Administration/US Army Corps of Engineers Hydrometeorological Report 59, p 419 [accessible online at http://www.nws.noaa.gov/oh/hdsc/]

Daly C, Neilson RP, Phillips DL (1994) A statistical-topographic model for mapping climatological precipitation over mountainous terrain. J Appl Meteor 33:140-158

Dettinger MD (2004) Fifty-two years of pineapple-express storms across the West Coast of North America. California Energy Commission PIER Energy-Related Environmental Research Report CEC-500-2005004, p 15

Dettinger MD (2011) Climate change, atmospheric rivers and floods in California — a multimodel analysis of storm frequency and magnitude changes. J Amer Water Resour Assoc 47:514-523

Dudhia J (1989) Numerical study of convection observed during the winter monsoon experiment using a mesoscale two-dimensional model. J Atmos Sci 46:3077-3107

Engstrom WN (1996) The California storm of January 1862. Quat Res 46:141-148

Florsheim JL, Dettinger M (2007) Climate and floods still govern California levee breaks. Geophys Res Lett 34(L22403):5. doi:10.1029/2007GL031702

Hamlet AF, Lettenmaier DP (2005) Production of temporally consistent gridded precipitation and temperature fields for the continental U.S. J Hydrometeor 6:330-336

Higgins RW, Schemm J-KE, Shi W, Leetmaa A (2000) Extreme precipitation events in the western United States related to tropical forcing. J Clim 13:793-820

Hong S-Y, Noh Y, Dudhia J (2006) A new vertical diffusion package with an explicit treatment of entrainment processes. Mon Wea Rev 134:2318-2341

Hughes M, Hall A, Fovell RG (2009) Blocking in areas of complex topography, and its influence on rainfall distribution. J Atmos Sci 66:508-518

Kain JS (2004) The Kain-Fritsch convective parameterization: An update. J Appl Meteor 43:170-181

Kalnay E, Kanamitsu M, Kistler R, Collins W, Deaven D, Gandin L, Iredell M, Saha S, White G, Woollen J, Zhu Y, Chelliah M, Ebisuzaki W, Higgins W, Janowiak J, Mo KC, Ropelewski C, Wang J, Leetmaa A, Reynolds R, Jenne R, Joseph D (1996) The NCEP/NCAR 40-year reanalysis project. Bull Amer Meteor Soc 77:437-471

Kelley R (1998) Battling the inland sea-floods, public policy and the Sacramento Valley. University of California Press, p 420

Kimball JS, Running SW, Nemani R (1997) An improved method for estimating surface humidity from daily minimum temperature. Agric For Meteorol 85:87-98

Kistler R, Kalnay E, Collins W, Saha S, White G, Woollen J, Chelliah M, Ebisuzaki W, Kanamitsu M, Kousky V, van den Dool H, Jenne R, Fiorino M (2001) The NCEP-NCAR 50-year reanalysis: monthly means CD-ROM and documentation. Bull Amer Meteor Soc 82:247-267

Leung LR, Qian Y (2009) Atmospheric rivers induced heavy precipitation and flooding in the Western U.S. simulated by the WRF regional climate model. Geophys Res Lett 36(L03820). doi:10.1029/2008 GL036445

Liang, X, Lettenmaier DP, Wood EF, Burges SJ (1994) A Simple hydrologically based model of land surface water and energy fluxes for GSMs. J Geophys Res 99(D7):14415-14428

Maurer EP, Wood AW, Adam JC, Lettenmaier DP, Nijssen B (2002) A long-term hydrologically-based data set of land surface fluxes and states for the conterminous United States. J Clim 15:3237-3251 
Mlawer EJ, Taubman SJ, Brown PD, Iacono MJ, Clough SA (1997) Radiative transfer for inhomogeneous atmosphere: RRTM, a validated correlated-k model for the longwave. J Geophys Res 102(D14): $16663-16682$

Monin AS, Obukhov AM (1954) Basic laws of turbulent mixing in the surface layer of the atmosphere. Contrib Geophys Inst Acad Sci USSR 151:163-187 (in Russian)

Morrison H, Thompson G, Tatarskii V (2009) Impact of cloud microphysics on the development of trailing stratiform precipitation in a simulated squall line: comparison of one- and two-moment schemes. Mon Wea Rev 137:991-1007

National Research Council (NRC) (1995) Flood risk management and the American River basin, an evaluation. National Academies Press, Washington, DC, ISBN 030905334X

National Research Council (NRC) (1999) Improving American River flood frequency analysis. National Academies Press, Washington, DC

National Weather Service (NWS) (1989) National Weather Service Observing Handbook Number 2. Cooperative Station Observations. Observing Systems Branch, Office of Systems Operations, $94 \mathrm{pp}$. [Available at, 3 February 2010, at http://www.nws.noaa.gov/om/coop/Publications/coophandbook2.pdf]

Neiman PJ, Ralph FM, Wick GA, Kuo YH, Wee TK, Ma Z, Taylor GH, Dettinger MD (2008) Diagnosis of an intense atmospheric river impacting the Pacific Northwest-storm summary and offshore vertical structure observed with COSMIC satellite retrievals. Mon Wea Rev 136:4398-4420. doi:10.1175/ 2008MWR2550.1

Null J, Hulbert J (2007) California washed away-the great flood of 1862. Weatherwise 59:27-30

Perica S, Dietz S, Heim S, Hiner L, Maitaria K, Martin D, Pavlovic S, Roy I, Trypaluk C, Unruh D, Yan F, Yekta M, Zhao T, Bonnin G, Brewer D, Chen L-C, Parzybok T, Yarchoan J (2011) Precipitationfrequency atlas of the United States, vol 6 version 2.0 California. NOAA Atlas 14, p 239. [Accessible online at http://www.nws.noaa.gov/oh/hdsc/]

Perry S, Cox D, Jones L, Bernknopf R, Goltz J, Hudnut K, Mileti D, Ponti D, Porter K, Reichle M, Seligson H, Shoaf K, Treiman J, Wein A (2008) The ShakeOut earthquake scenario-a story that southern Californians are writing. USGS Circular 1324, p 24. [Available from USGS Information Services, Box 25286, Federal Center, Denver, CO 80225.]

Porter K, Wein A, Alpers C, Baez A, Barnard P, Carter J, Corsi A, Costner J, Cox D, Das T, Dettinger M, Done J, Eadie C, Eymann M, Ferris J, Gunturi P, Hughes M, Jarrett R, Johnson L, Dam Le-Griffin H, Mitchell D, Morman S, Neiman P, Olsen A, Perry S, Plumlee G, Ralph M, Reynolds D, Rose A, Schaefer K, Serakos J, Siembieda W, Stock J, Strong D, Sue Wing I, Tang A, Thomas P, Topping K, Wills C (2011) Overview of the ARkStorm scenario. U.S. Geological Survey Open-File Report 2010-1312, p 183 and appendixes. [Available online at http://pubs.usgs.gov/of/2010/1312/]

Ralph FM, Neiman PJ, Wick GA (2004) Satellite and CALJET aircraft observations of atmospheric rivers over the eastern North-Pacific Ocean during the winter of 1997/98. Mon Wea Rev 132:1721-1745

Ralph FM, Rauber RM, Jewett BF, Kingsmill DE, Pisano P, Pugner P, Rassmussen RM, Reynolds DW, Schlatter TW, Stewart RE, Waldstreicher JS (2005a) Improving short-term (0-48 hour) cool-season quantitative precipitation forecasting: recommendations from a USWRP Workshop. Bull Amer Meteor Soc 86:1619-1632

Ralph FM, Neiman PJ, Rotunno R (2005b) Dropsonde observations in low-level jets over the northeastern Pacific Ocean from CALJET-1998 and PACJET-2001: mean vertical-profile and atmospheric-river characteristics. Mon Wea Rev 133:889-910. doi:10.1175/MWR2896.1

Ralph FM, Neiman PJ, Wick G, Gutman S, Dettinger M, Cayan D, White AB (2006) Flooding on California's Russian River-role of atmospheric rivers. Geophys Res Lett 33 (L13801):5. doi:10.1029/ 2006GL026689

Rehmeyer J (2006) Sacramento valley. In Barry P (ed) Sooner or later, the water will arrive, 190. New Scientist, pp 8-9

Roden GI (1989) Analysis and interpretation of long-term climatic variability along the west coast of North America. In Peterson DH (ed) Aspects of climate variability in the Pacific and the western Americas. Amer Geophysl Union Monograph 55:93-111

Sadler WA (1957, expanded and updated 1972) Floods of the past-an assemblage of documentary observations with particular reference to the San Bernardino Valley and environs. San Bernardino County Flood Control District Report, p 166 [obtained in scanned form from Miles Wagner, Emergency Services Officer, San Bernardino County Office of Emergency Services, 825 East $3{ }^{\text {rd }}$ Street, San Bernardino, CA 92415]

Sheffield J, Goteti G, Wen F, Wood EF (2004) A simulated soil moisture based drought analysis for the United States. J Geophys Res 109(D24):D24108 
Skamarock WC, Klemp JB, Dudhia J, Gill DO, Barker DM, Duda MG, Huang XY, Wang W, Powers JG (2008) Description of the Advanced Research WRF Version 3. NCAR Technical Note, NCAR/TN475 + STR [available, 3 February 2010, at http://www.ucar.edu/library/collections/technotes/]

Thompson J (1957) The settlement geography of the Sacramento-San Joaquin Delta, California. Unpublished Ph.D. dissertation, Stanford University

Thornton PE, Running SW (1999) An improved algorithm for estimating incident daily solar radiation from measurements of temperature, humidity, and precipitation. Agric For Meteorol 93:211-228

U.S. Army Corps of Engineers (1952, updated March 1965) Standard Project Flood Determinations. USACE Civil Engineering Bulletin 52-8, EM 1110-2-1411, 19 p., currently available at http://140. 194.76.129/publications/eng-manuals/em1110-2-1411/basdoc.pdf

Weaver RL (1962) Meteorology of hydrologically critical storms in California. Washington, D.C., U.S. Department of Commerce, Hydrometeor. Report No. 37 [available from University of California, Water Resources Center Archives, 410 O’Brien Hall, Berkeley, CA 94720-1718]

Wood EF, Lettenmaier DP, Zartarian VG (1992) A land-surface hydrology parameterization with subgrid variability for general circulation models. J Geophys Res 97(D3):2717-2728

Zhu Y, Newell RE (1998) A proposed algorithm for moisture fluxes from atmospheric rivers. Mon Wea Rev 126:725-735 